\title{
Income inequality and financial crises: evidence from the bootstrap rolling window
}

\author{
Mehmet Akif Destek* (D) and Bilge Koksel
}

\author{
* Correspondence: adestek@gantep. \\ edu.tr \\ This manuscript is based on \\ dissertation research of the first \\ author at the Department of \\ Economics, Gaziantep University. \\ Department of Economics, \\ Gaziantep University, 27310 \\ Gaziantep, Turkey
}

\begin{abstract}
This study aims to investigate the validity of the Rajan hypothesis, which argues that increasing income inequality plays a key role in the outbreak of financial crises. The relationship between income inequality and credit booms are examined in 10 developed countries: Australia, Canada, Denmark, Finland, France, the United Kingdom, Japan, Norway, Sweden, and the United States. In doing so, a bootstrap rolling-window estimation procedure is used to detect any possible causal link between inequality and credit booms in financial crisis sub-periods. The results reveal that the Rajan hypothesis is supported for the 1989 crisis in Australia, the 1991 and 2007 crises in the United Kingdom, and the 1929 and 2007 crises in the United States. Therefore, increasing income inequality has positive predictive power on credit booms in Anglo-Saxon countries. However, the hypothesis is not confirmed for Scandinavian and continental European countries. Our study is novel in its use of the bootstrap rolling-window procedure, which allows us to detect the possible relationship between inequality and credit booms in financial crises. The findings suggest that a progressive taxation policy or investments to accumulate human capital and increase the labor force are more beneficial than temporary solutions.

Keywords: Income inequality, Credit booms, Financial crisis, Rolling window estimation

JEL classifications: E25, E51, G01
\end{abstract}

\section{Introduction}

In pioneer studies of crisis theories, Fisher $(1932,1933)$ argued that all economic booms and depressions emerge through excessive borrowing and subsequent deflation. Following this argument, Minsky's (1975, 1982, 1986) financial instability hypothesis argued that financial instability primarily occurs due to excessive borrowing, but these hypotheses are based on corporate debt and investments rather than household debt and consumption. In addition, many studies have highlighted the risk associated with excessive bank lending affects financial systems and entire economies (Kashif et al. 2016). Therefore, it is necessary to examine the bases of financial instability through debt and credit expansion (Perugini et al. 2015).

Financial instability has been explained following these perspectives, and by incorporating many factors: banks' herd behavior (Kindleberger 1978); credit policies based on

(c) The Author(s). 2019 Open Access This article is distributed under the terms of the Creative Commons Attribution 4.0 International License (http://creativecommons.org/licenses/by/4.0/), which permits unrestricted use, distribution, and reproduction in any medium, provided you give appropriate credit to the original author(s) and the source, provide a link to the Creative Commons license, and indicate if changes were made. 
inter-bank dependency caused by the information problem (Rajan 1994); underestimated risks (Borio et al. 2001); existing government guarantees (Corsetti et al. 1999); loose credit standards (Dell'Ariccia and Marquez 2006); borrowers' limited commitment (Lorenzoni 2005); and the nature of business cycles and financial accelerators (Bernanke et al. 1999). Similarly, the recent 2007 global financial crisis is associated with many factors, such as financial deregulation policies, households' excessive borrowing, Wall Street's ethically deficient culture, and the securitization of mortgages (Yamarik et al. 2016). Recently, many researchers have proposed an alternative view that income inequality may have had an important role in the outbreak of the 2007 financial crisis (Rajan 2010; Reich 2010; Roubini 2011; Milanovic 2009; Galbraith 2012; Stiglitz 2012; Krueger 2012; Palley 2012; Van Treeck 2014).

The International Monetary Fund's Chief Economist Raghuram Rajan, in his 2010 book Fault Lines, notes that increasing income inequality in the United States has put pressure on governments. He also argues that governments with voting anxiety have facilitated credit access for voters in low- and middle-income groups, rather than implementing policies to reduce income inequality. The government has also ensured these income groups' credit access by implementing deregulation policies in credit markets, and has encouraged state-owned mortgage agencies' loans to low-income segments. As a result of these subsidized loans, although debt remained sustainable for a while, this has become unsustainable, and a credit bubble and subsequent crisis have emerged as a result of these policies.

However, Acemoglu (2011) argues that Rajan's views can be misinterpreted, as no one-way, cause-and-effect relationship exists between inequality and the financial crisis. Further, Acemoglu states that Rajan's causal relations in the hypothesis are correctly explained by income inequality to political pressure, and from political pressure to credit expansion, but the actual relationship leans toward an unstable financial situation due to policy pressures and the inequality and credit expansion from financial instability. According to Acemoglu, the government's pressure on the financial system has resulted in the coexistence of inequality and financial crises. Specifically, increasing income inequality has led to an increase in political forces among high-income segments, which earn their high income largely from the financial system. This segment displays their increased political power by pressuring governments toward financial deregulation, and such financial deregulation has led to inequality and financial instability.

Finally, financial instability has again led to the increase of political forces among this segment. In short, Acemoglu's (2011) work differs from Rajan's, in that Acemoglu has established a feedback relationship between inequality and financial crises; the primary difference between Acemoglu's and Rajan's hypotheses is the origin of pressures to deregulate.

This study considers the discussions above in its aim to examine the relationship between income inequality and financial crises in 10 selected countries-Australia, Canada, Denmark, Finland, France, the United Kingdom, Japan, Norway, Sweden, and the United States-by using a bootstrap rolling-window procedure. These countries were selected because this study's empirical method requires a long sample window, and all these countries have historical databases. Additionally, previous studies on testing the role of income inequality in financial crises used credit expansion to indicate such crises. These studies confirm the validity of Rajan hypothesis if a unidirectional causality exists from income inequality to credit boom, and the Acemoglu hypothesis if 
a bidirectional causal link exists. However, previous studies ignored one key detail: all credit booms are not followed by a banking crisis. Therefore, the rolling-window estimation method-which allows for an examination of the time-varying causal relationships between variables-provides an opportunity to detect the possible relationship between inequality and credit booms in financial crisis periods.

In summary, we primarily argue that the presence of unidirectional causality from inequality to credit booms within the full sample does not adequately justify accepting the Rajan hypothesis. However, the hypothesis can be confirmed under two conditions. First, the presence of causality from inequality to credit booms should occur in the crisis sub-period. Second, the coefficient of inequality in credit booms should be positive in this sub-period.

This study makes three contributions to the literature: i) This is the first study to investigate the causal relationship between income inequality and financial crisis using a rolling-window causality procedure in its selected countries. ii) As using unit root tests that ignore possible structural breaks may provide misleading results, this study employs a unit root test with multiple endogenous structural breaks. iii) This study also provides a methodological contribution by employing a bootstrap rolling-window estimation method, which has never been previously used in such research; this methodology lets us separate the findings into sub-sample periods.

\section{Literature review}

This section reviews empirical studies investigating whether income inequality may be a major reason for credit booms and financial crises. In addition to these empirical studies, agent-based studies also address the nexus between inequality and crises.

For instance, Dosi et al. (2013) examined the relationship between income distribution and monetary policy using a credit-augmented version of the agent-based Keynesian model, and concluded that more unequal economies experience a higher probability of crises. Kumhof et al. (2015) explored the nexus between income distribution, household leverage, and crises using an agent-based approach, and argued that higher leverage and crises are the endogenous result of high-income households' growing share of income. Similarly, Russo et al. (2016) argued that increasing inequality accelerates the system's tendency toward crisis.

Limited studies have also empirically addressed the view that the increasing income inequality plays a key role in the emergence of financial crises. This perspective is also known as the Rajan hypothesis, and empirical studies appear to have examined this based on the hypothesis that increasing inequality not only creates unsustainable levels of household debt and leads to a credit bubble, but also impacts credit expansion as well as household debt.

It can be observed that studies investigating the validity of the hypothesis for the same countries or country groups based on the observed period or used methodology reveal contradictory findings. For instance, Bordo and Meissner (2012) examined the relationship between income inequality and credit expansion in 14 developed countries using a panel fixed-effects model for the period from 1920 to 2012, and concluded that the Rajan hypothesis is invalid for their observed country group. In contrast, Kirschenmann et al. (2016) examined the validity of Rajan hypothesis in the same country group using a panel logit model for the period from 1870 to 2008 to conclude that the hypothesis is valid. 
Similarly, Malinen (2013) employed a seemingly unrelated dynamic regression to explore the relationship between income inequality and credit expansion in the case of eight developed countries from 1972 to 2008, and concluded that no relationship exists between income inequality and credit expansion. However, Gu and Huang (2012) probed this nexus in the same country group from 1980 to 2008 using a pooled mean-group estimation approach to conclude that the hypothesis is valid for three of the eight countries.

Further, it seems that some existing studies focused on countries within the Organisation for Economic Co-operation and Development (OECD) and found evidence to confirm the Rajan hypothesis. Ahlquist and Ansell (2012) analyzed the validity of this hypothesis through a panel error-correction model from 1980 to 2008 in OECD countries, and concluded that the Rajan hypothesis is valid. Additionally, Perugini et al. (2015) verified the validity of the Rajan hypothesis in OECD countries using the panel generalized method of moments (GMM) estimation method from 1970 to 2007. Mahmoud and Niguez (2015) also confirmed its validity in 18 OECD countries from 1970 to 2007 using a panel GMM procedure.

Some studies investigate the possible role of increasing inequality in global financial crises by examining this nexus in the US economy; these studies also present contradictory findings. Fasianos et al. (2017) investigated the relationship between income inequality and credit expansion in the United States from 1913 to 2008 using a nonlinear autoregressive distributed lag test to invalidate the Rajan hypothesis. In contrast, Yamarik et al. (2016) examined the validity of the hypothesis among the 50 US states from 1977 to 2010 using with second-generation panel data methodologies to consider the cross-sectional dependence among states. This study's findings reveal that the hypothesis is valid.

As the literature has indicated, all studies on the relationship between inequality and crises have used credit expansion as an absolute crisis indicator. However, not every credit expansion has resulted in a crisis. Therefore, this study deviates from previous works to examine the emergence of crises in periods when income inequality has caused credit expansion. Additionally, previous studies' empirical analyses have been based on the assumption of stable parameters; this study first tests the stability of parameters and then conducts an analysis based on the parameter instability.

\section{Data and methodology}

This study examines the relationship between income inequality and financial crises in 10 selected countries-Australia, Canada, Denmark, Finland, France, the United Kingdom, Japan, Norway, Sweden and the United States-including annual data with different sample periods for each country based on data availability. Specifically, we use 1886-2013 data for Japan; 1913-2013 data for the United States; 1920-2013 data for Australia, Canada, Denmark, Finland, and France; 1948-2013 data for Norway; 1949-2013 data for the United Kingdom; and 1943-2013 data for Sweden.

We follow Bordo and Meissner's (2012) study and use "credit expansion" to indicate financial crises. Subsequently, a bank loan variable is deflated by the consumer price index and used as a proxy for credit expansion (hereafter, "CRE"). Additionally, the share of total income earned by the top $1 \%$ of households is used to indicate income inequality (INE). Bank loan and consumer price index data are obtained from Schularick 
and Taylor's (2012) Macrohistory database, and income inequality data are retrieved from the World Top Incomes Database. Further, we also conducted a robustness check with real mortgage loans as an indicator of credit expansion to observe the impact of income inequality on mortgage loans. The mortgage loans series data are also obtained from the Macrohistory database.

In testing our procedure, we first used the full-sample bootstrap causality method as developed by Hacker and Hatemi-J (2006); this is a modified version of Toda and Yamamoto's (1995) causality method, which allows us to investigate the variables' causal relationships and determine whether they are co-integrated. The test's critical values are obtained from Efron's (1979) bootstrap testing procedure. The first step of this methodology considers the following vector autoregressive (VAR) process:

$$
y_{t}=\phi_{0}+\phi_{1} y_{t-1}+\ldots+\phi_{p} y_{t-p}+\varepsilon_{t}, t=1,2, \ldots, T
$$

where $p$ is the lag order, $\varepsilon t=(\varepsilon 1 t, \varepsilon 2 t)^{\prime}$ is the zero-mean white-noise process with covariance matrix $\Sigma$. Further, $y t$ is split into two vectors-CRE $(y 1 t)$ and INE $(y 2 t)$-to ultimately obtain

$$
\left[\begin{array}{l}
y_{1 t} \\
y_{2 t}
\end{array}\right]=\left[\begin{array}{l}
\phi_{10} \\
\phi_{20}
\end{array}\right]+\left[\begin{array}{ll}
\phi_{11}(L) & \phi_{12}(L) \\
\phi_{21}(L) & \phi_{22}(L)
\end{array}\right]\left[\begin{array}{l}
y_{1 t} \\
y_{2 t}
\end{array}\right]+\left[\begin{array}{l}
\varepsilon_{1 t} \\
\varepsilon_{2 t}
\end{array}\right]
$$

where $\phi_{i j}(L)=\sum_{k-1}^{p} \phi_{i j, k} L^{k}, i, j=1,2$ and $L$ is the lag operator. The null hypothesis of income inequality (INE) does not Granger-cause credit growth (CRE) can be examined by imposing zero restrictions $\phi_{12, i}=0$ for $i=1,2, \ldots, p$ and the null of credit growth (CRE) does not Granger-cause income inequality (INE) can be computed by imposing zero restrictions $\phi_{21, i}=0$ for $i=1,2, \ldots, p$.

Various empirical analyses describe different methods to determine structural changes, such as splitting the sample into pieces or using dummy variables, among others. This study uses the rolling-window causality method as described by Balcilar et al. (2010) to consider the changes in the causal relationship between income inequality and credit growth for sub-sample periods. Balcilar et al. (2010) used Hacker and Hatemi-J's (2006) methodology to develop a causality method that investigates the bootstrap causality in rolling-window sub-samples for $t=\tau-1+l, \tau-1, \ldots, \tau, \tau=l, l+1, \ldots, T$, where $l$ is the rolling window. Possible changes in the causal connections between inequality and credit growth are determined by computing the bootstrap $p$-values of the LR-statistic rolling through T-1 sub-samples. Further, the effect of income inequality on credit growth is calculated as $B^{-1} \sum_{k-1}^{P} \hat{\phi}_{21, k}^{*}$ with $\hat{\phi}_{21, k}^{*}$ obtained from bootstrap estimation of vector autoregressive (VAR) model by Eq.2 and $B$ is the bootstrap repetition number. Similarly, the effect of credit growth on income inequality is computed as $B^{-1} \sum_{k-1}^{P} \hat{\phi}_{12, k}^{*}$ where $\hat{\phi}_{12, k}^{*}$ is obtained from bootstrap estimation of VAR model by Eq. 2 and $B$ refers to bootstrap repetition number.

\section{Empirical results}

Investigating the stationary process of variables in an empirical analysis is a crucial issue, as ignoring any possible structural breaks may lead to unreliable results. We address this problem by first using a unit root test that allows multiple structural breaks (hereafter, "CS") as developed by Carrion-i-Silvestre et al. (2009). Table 1 
Table 1 CS unit root test results with structural breaks

\begin{tabular}{|c|c|c|c|c|c|}
\hline Countries & Statistics & InCRE & $\triangle \operatorname{lnCRE}$ & INE & $\triangle \mathrm{INE}$ \\
\hline \multirow[t]{3}{*}{ Australia } & $M Z_{a}^{G L S}$ & $-17.878[-31.667]$ & $-35.940[-28.679]$ & $-11.593[-28.655]$ & $-35.401[-28.098]$ \\
\hline & $M Z_{t}^{G L S}$ & $-2.911[-3.963]$ & $-4.223[-3.734]$ & $-2.341[-3.737]$ & $-4.193[-3.742]$ \\
\hline & Break Dates & $1930,1947,1983$ & & $1929,1945,1983$ & \\
\hline \multirow[t]{3}{*}{ Canada } & $M Z_{a}^{G L S}$ & $-12.710[-34.937]$ & $-42.636[-36.251]$ & $-14.081[-23.071]$ & $-35.105[-24.111]$ \\
\hline & $M Z_{t}^{G L S}$ & $-2.483[-4.162]$ & $-4.607[-4.237]$ & $-2.605[-3.297]$ & $-4.183[-3.482]$ \\
\hline & Break Dates & $1929,1943,1981$ & & $1930,1991,2000$ & \\
\hline \multirow[t]{3}{*}{ Denmark } & $M Z_{a}^{G L S}$ & $-5.448[-27.254]$ & $-30.996[-21.022]$ & $-16.781[-36.05]$ & $-44.140[-35.495]$ \\
\hline & $M Z_{t}^{G L S}$ & $-1.596[-3.624]$ & $-3.922[-3.148]$ & $-2.874[-4.217]$ & $-4.691[-4.188]$ \\
\hline & Break Dates & $1939,1961,2004$ & & $1939,1957,1973$ & \\
\hline \multirow[t]{3}{*}{ Finland } & $M Z_{a}^{G L S}$ & $-11.497[-31.340]$ & $-35.755[-29.598]$ & $-12.177[-28.966]$ & $-41.615[-31.887]$ \\
\hline & $M Z_{t}^{G L S}$ & $-2.388[-3.946]$ & $-4.288[-3.798]$ & $-2.467[-3.798]$ & $-4.560[-3.983]$ \\
\hline & Break Dates & $1931,1948,1990$ & & $1948,1974,1992$ & \\
\hline \multirow[t]{3}{*}{ France } & $M Z_{a}^{G L S}$ & $-30.471[-34.781]$ & $-42.743[-31.880]$ & $-24.119[-29.038]$ & $-40.190[-28.893]$ \\
\hline & $M Z_{t}^{G L S}$ & $-3.902[-4.148]$ & $-4.622[-3.954]$ & $-3.463[-3.763]$ & $-4.481[-3.754]$ \\
\hline & Break Dates & $1936,1945,1975$ & & $1936,1945,1957$ & \\
\hline \multirow[t]{3}{*}{ United Kingdom } & $M Z_{a}^{G L S}$ & $-9.933[-34.429]$ & $-35.389[-34.846]$ & $-15.329[-35.391]$ & $-44.910[-26.218]$ \\
\hline & $M Z_{t}^{G L S}$ & $-2.228[-4.130]$ & $-4.206[-4.157]$ & $-2.760[-4.189]$ & $-4.734[-3.613]$ \\
\hline & Break Dates & $1957,1991,2007$ & & $1973,1987,2007$ & \\
\hline \multirow[t]{3}{*}{ Japan } & $M Z_{a}^{G L S}$ & $-20.339[-33.682]$ & $-45.873[-34.538]$ & $-18.930[-31.658]$ & $-44.494[-26.113]$ \\
\hline & $M Z_{t}^{G L S}$ & $-3.171[-4.100]$ & $-4.789[-4.143]$ & $-3.057[-3.965]$ & $-4.702[-3.604]$ \\
\hline & Break Dates & $1944,1973,1993$ & & $1904,1944,1990$ & \\
\hline \multirow[t]{3}{*}{ Norway } & $M Z_{a}^{G L S}$ & $-16.273[-31.843]$ & $-45.689[-32.505]$ & $-26.609[-32.709]$ & $-39.852[-32.009]$ \\
\hline & $M Z_{t}^{G L S}$ & $-2.846[-3.980]$ & $-4.779[-4.020]$ & $-3.631[-4.026]$ & $-4.463[-3.983]$ \\
\hline & Break Dates & $1980,1987,2007$ & & $1991,1998,2007$ & \\
\hline \multirow[t]{3}{*}{ Sweden } & $M Z_{a}^{G L S}$ & $-8.636[-32.118]$ & $-37.404[-33.631]$ & $-12.943[-33.640]$ & $-42.480[-35.990]$ \\
\hline & $M Z_{t}^{G L S}$ & $-2.077[-3.998]$ & $-4.322[-4.083]$ & $-2.525[-4.088]$ & $-4.588[-4.226]$ \\
\hline & Break Dates & $1951,1979,1992$ & & $1975,1982,2000$ & \\
\hline \multirow[t]{3}{*}{ United States } & $M Z_{a}^{G L S}$ & $-15.204[-35.371]$ & $-32.854[-31.474]$ & $-14.692[-33.262]$ & $-38.395[-32.467]$ \\
\hline & $M Z_{t}^{G L S}$ & $-2.696[-4.180]$ & $-4.016[-3.963]$ & $-2.652[-4.049]$ & $-4.377[-4.019]$ \\
\hline & Break Dates & $1929,1942,1965$ & & $1929,1946,1984$ & \\
\hline
\end{tabular}

Note: Numbers in brackets are critical values at 5\% significance level that obtained from 1000 bootstrap simulations. $\Delta$ indicates the first difference operator

illustrates the CS results, which show that the null of the unit root is not rejected at the level form of variables for all countries. However, the null hypothesis in its first differenced form can be rejected at a $5 \%$ significance level for all countries, and thus, all variables have become stationary. This finding also shows that all variables are integrated at I (1).

The next step examines the causal relationship between income inequality and credit expansion using Hacker and Hatemi-J's (2006) full-sample bootstrap Granger causality test. Table 2 presents the full sample's causality test results. Based on the findings, we determined that a unidirectional causality exists from income inequality to credit expansion for Australia, Canada, Sweden, and the United States. This finding suggests that the Rajan hypothesis is valid in these countries. Moreover, a bidirectional causality 
Table 2 Full Sample Bootstrap Granger Causality Test Results

\begin{tabular}{|c|c|c|c|c|c|c|}
\hline \multirow[t]{2}{*}{ Countries } & \multirow{2}{*}{$\begin{array}{l}\text { Null } \\
\text { Hypothesis }\end{array}$} & \multirow[t]{2}{*}{ MWALD } & \multirow{2}{*}{$\begin{array}{l}\operatorname{VAR}(\mathrm{p} \\
+ \\
\left.\mathrm{d}_{\max }\right)\end{array}$} & \multicolumn{3}{|c|}{ Critical Values } \\
\hline & & & & $1 \%$ & $5 \%$ & $10 \%$ \\
\hline \multirow[t]{2}{*}{ Australia } & $I N E \nRightarrow C R E$ & $4.140^{\mathrm{a}}$ & 2 & 9.653 & 4.184 & 3.431 \\
\hline & $\mathrm{CRE} \nRightarrow \mathrm{INE}$ & 0.484 & 2 & 6.132 & 3.856 & 2.577 \\
\hline \multirow[t]{2}{*}{ Canada } & $\mathrm{INE} \nRightarrow \mathrm{CRE}$ & $9.532^{c}$ & 3 & 7.594 & 5.184 & 4.120 \\
\hline & $\mathrm{CRE} \nRightarrow \mathrm{INE}$ & 0.005 & 3 & 14.635 & 6.833 & 4.912 \\
\hline \multirow[t]{2}{*}{ Denmark } & INE $\nRightarrow C R E$ & 2.281 & 3 & 14.009 & 9.438 & 5.763 \\
\hline & $\mathrm{CRE} \nRightarrow \mathrm{INE}$ & $7.095^{b}$ & 3 & 9.594 & 6.426 & 4.926 \\
\hline \multirow[t]{2}{*}{ Finland } & INE $\nRightarrow C R E$ & 3.865 & 3 & 10.678 & 6.576 & 4.571 \\
\hline & $\mathrm{CRE} \nRightarrow \mathrm{INE}$ & 0.159 & 3 & 12.608 & 6.596 & 5.622 \\
\hline \multirow[t]{2}{*}{ France } & INE $\nRightarrow C R E$ & 0.391 & 2 & 10.039 & 5.011 & 3.078 \\
\hline & $\mathrm{CRE} \nRightarrow \mathrm{INE}$ & 0.250 & 2 & 5.554 & 3.361 & 2.503 \\
\hline \multirow[t]{2}{*}{ UK } & INE $\nRightarrow C R E$ & 1.102 & 3 & 8.151 & 6.834 & 4.899 \\
\hline & $\mathrm{CRE} \nRightarrow \mathrm{INE}$ & $5.777^{a}$ & 3 & 10.261 & 7.126 & 5.345 \\
\hline \multirow[t]{2}{*}{ Japan } & INE $\nRightarrow C R E$ & $17.209^{b}$ & 4 & 39.079 & 9.147 & 6.240 \\
\hline & $\mathrm{CRE} \nRightarrow \mathrm{INE}$ & $10.059^{b}$ & 4 & 34.325 & 9.752 & 7.645 \\
\hline \multirow[t]{2}{*}{ Norway } & INE $\nRightarrow C R E$ & 0.108 & 2 & 8.497 & 4.236 & 3.010 \\
\hline & $\mathrm{CRE} \nRightarrow \mathrm{INE}$ & 0.428 & 2 & 5.788 & 3.852 & 2.661 \\
\hline \multirow[t]{2}{*}{ Sweden } & $\mathrm{INE} \nRightarrow \mathrm{CRE}$ & $6.355^{b}$ & 3 & 8.122 & 5.507 & 4.239 \\
\hline & $\mathrm{CRE} \nRightarrow \mathrm{INE}$ & 3.939 & 3 & 11.925 & 7.378 & 4.992 \\
\hline \multirow[t]{2}{*}{ US } & $I N E \nRightarrow C R E$ & $8.592^{b}$ & 3 & 10.080 & 5.103 & 4.340 \\
\hline & $\mathrm{CRE} \nRightarrow \mathrm{INE}$ & 0.483 & 3 & 9.451 & 6.420 & 5.404 \\
\hline
\end{tabular}

Note: ${ }^{a},{ }^{b}$ and ${ }^{c}$ indicates statistical significance at 10,5 and $1 \%$ level, respectively. Optimum lag lengths are selected with using HJC information criteria

exists in Japan between income inequality and credit expansion as argued by the Acemoglu hypothesis. However, this finding reveals no causal connection between inequality and credit expansion in Finland, France, and Norway.

We follow this study's main arguments in examining the stability of full sample parameters with four tests to measure the full sample's reliability; Table 3 presents the parameter stability test results. We first use Phillips and Hansen's (1990) LC test for each fully modified ordinary least squares (OLS) equation; the results indicate that the null of the long-run parameter constancy is rejected in all countries regarding the credit equation. Additionally, we implement Andrews' (1993) Sup-LR test to consider swift regime shifts, and Andrews and Ploberger's (1994) Exp-LR and Mean-LR tests to determine whether the model captures a stable relationship over time. Regarding the credit equation, the Sup-LR test indicates parameter instability, and the Exp-LR test rejects the null of parameter constancy for all countries. The Mean-LR test also rejects the parameter stability for all countries, excluding Japan and the United States. In summary, when the parameter stability test findings are evaluated, it can be observed that the parameters for this relationship are unstable; thus, the obtained parameters do not reflect the entire observed period. Specifically, according to the findings from previous studies based on the assumption of parameter stability, it cannot be claimed based on only one parameter that inequality causes financial crises. These results will be more consistent if the relationship is divided into sub-observations according to the crisis periods. 
Table 3 Parameter Stability Test Results

\begin{tabular}{|c|c|c|c|c|c|}
\hline & & \multicolumn{2}{|c|}{ INE equation } & \multicolumn{2}{|c|}{ CRE equation } \\
\hline & & Statistics & $p$-value & Statistics & $p$-value \\
\hline \multirow[t]{4}{*}{ Australia } & Sup-LR & 3.555 & 0.068 & 2.879 & 0.057 \\
\hline & Exp-LR & 0.621 & 0.203 & 1.047 & 0.005 \\
\hline & Mean-LR & 1.075 & 0.260 & 1.937 & 0.005 \\
\hline & $L_{C}$ & 0.528 & 0.034 & 0.829 & $<0.01$ \\
\hline \multirow[t]{4}{*}{ Canada } & Sup-LR & 1.543 & 0.698 & 8.572 & 0.000 \\
\hline & Exp-LR & 0.434 & 0.605 & 1.190 & 0.015 \\
\hline & Mean-LR & 0.832 & 0.609 & 1.586 & 0.087 \\
\hline & $\mathrm{L}_{C}$ & 0.565 & 0.027 & 0.687 & $<0.01$ \\
\hline \multirow[t]{4}{*}{ Denmark } & Sup-LR & 3.591 & 0.010 & 3.309 & 0.031 \\
\hline & Exp-LR & 0.850 & 0.042 & 1.114 & 0.006 \\
\hline & Mean-LR & 1.486 & 0.070 & 2.202 & 0.005 \\
\hline & $L_{C}$ & 0.925 & $<0.01$ & 1.153 & $<0.01$ \\
\hline \multirow[t]{4}{*}{ Finland } & Sup-LR & 2.845 & 0.285 & 4.255 & 0.097 \\
\hline & Exp-LR & 0.781 & 0.194 & 1.149 & 0.070 \\
\hline & Mean-LR & 1.467 & 0.162 & 2.095 & 0.057 \\
\hline & $L_{C}$ & 0.275 & 0.175 & 1.306 & $<0.01$ \\
\hline \multirow[t]{4}{*}{ France } & Sup-LR & 3.955 & 0.011 & 1.778 & 0.015 \\
\hline & Exp-LR & 1.509 & 0.010 & 0.785 & 0.013 \\
\hline & Mean-LR & 3.604 & 0.041 & 3.530 & 0.024 \\
\hline & $L_{C}$ & 1.462 & $<0.01$ & 1.277 & $<0.01$ \\
\hline \multirow[t]{4}{*}{ UK } & Sup-LR & 1.966 & 0.539 & 3.123 & 0.085 \\
\hline & Exp-LR & 0.496 & 0.519 & 0.888 & 0.067 \\
\hline & Mean-LR & 0.945 & 0.510 & 1.610 & 0.078 \\
\hline & $L_{C}$ & 1.041 & $<0.01$ & 0.913 & $<0.01$ \\
\hline \multirow[t]{4}{*}{ Japan } & Sup-LR & 3.120 & 0.052 & 5.873 & 0.002 \\
\hline & Exp-LR & 0.572 & 0.297 & 0.838 & 0.058 \\
\hline & Mean-LR & 0.910 & 0.520 & 1.355 & 0.121 \\
\hline & $L_{C}$ & 0.589 & 0.023 & 0.723 & $<0.01$ \\
\hline \multirow[t]{4}{*}{ Norway } & Sup-LR & 3.698 & 0.082 & 3.328 & 0.060 \\
\hline & Exp-LR & 0.992 & 0.041 & 0.876 & 0.061 \\
\hline & Mean-LR & 1.730 & 0.043 & 1.690 & 0.053 \\
\hline & $L_{C}$ & 0.729 & $<0.01$ & 0.983 & $<0.01$ \\
\hline \multirow[t]{4}{*}{ Sweden } & Sup-LR & 3.194 & 0.086 & 3.346 & 0.085 \\
\hline & Exp-LR & 0.750 & 0.140 & 0.914 & 0.061 \\
\hline & Mean-LR & 1.388 & 0.141 & 1.734 & 0.053 \\
\hline & $L_{C}$ & 0.692 & $<0.01$ & 0.994 & $<0.01$ \\
\hline \multirow[t]{4}{*}{ US } & Sup-LR & 3.426 & 0.016 & 7.464 & 0.000 \\
\hline & Exp-LR & 0.920 & 0.023 & 1.446 & 0.000 \\
\hline & Mean-LR & 1.768 & 0.022 & 1.396 & 0.105 \\
\hline & $\mathrm{L}_{C}$ & 0.877 & $<0.01$ & 0.719 & $<0.01$ \\
\hline
\end{tabular}

Note: The parameter stability test for all parameters are based on VAR (3) jointly estimates 
Based on the parameter instability for the full sample period, we used the rolling-window estimation method to observe the relationship between inequality and credit expansion among the sub-sample periods. Additionally, using this method lets us detect the presence of a causal relationship between inequality and credit expansion during the financial crisis periods.

Figures 1, 2, 3, 4, 5, 6, 7, 8, 9 and 10 plot all sample countries' rolling-window estimation results. Panels $\mathrm{A}$ and $\mathrm{B}$ in each figure reveal the bootstrap p-values of the rolling test statistics, which test whether the null hypothesis of income inequality does not Granger-cause credit expansion, and vice versa. Panels C and D in each figure display the bootstrap estimates of the sum of the rolling coefficients, which measure the effect of income inequality on credit expansion, and vice versa. The results for Australia as given in Panel A in Fig. 1 demonstrate that the null of income inequality does not cause credit expansion, ${ }^{1}$ and thus, is rejected for the 1977-1982 and 1989-1998 sub-periods. Panel C in Fig. 1 notes that the inequality's impact on credit expansion is positive in these sub-periods. According to Schularick and Taylor (2012), Australia's systemic banking crisis emerged in 1989. Therefore, the results reveal that the causality from income inequality to credit expansion-or the Rajan hypothesis-is valid for the crisis period. Additionally, the plot in Panel B of Fig. 1 reveals that a causality from credit to inequality does not exist in the crisis period; thus, the Acemoglu hypothesis is not valid.

In Canada's case, according to Schularick and Taylor's (2012) crisis database, no banking crisis occurred in the observed period. The rolling-window estimation results from Panel A in Fig. 2 indicate that the null of income inequality does not cause credit expansion, and is only rejected for the 1954-1957 sub-period. Panel C in Fig. 2 also indicates that inequality's impact on credit expansion is positive for the previously mentioned period. However, this causal connection has not led to a crisis. Moreover, Panel B in Fig. 2 reveals that the causality from credit expansion to income inequality is rejected for almost all observations. Based on these results, it can be said that both the Rajan and Acemoglu hypotheses are unconfirmed for Canada, while income inequality's credit-increasing effect is valid for most of the sub-sample periods.

Figure 3 plots the rolling-window estimation results for Denmark. According to Schularick and Taylor (2012), banking crises emerged in Denmark in 1987 and 2008. Panel A in Fig. 3 indicates that the causality from income inequality to credit expansion is valid for the 1998-2003 sub-period. While inequality's impact on credit expansion is positive in this period, no banking crisis occurred. Panel B in Fig. 3 reveals that the null of credit expansion does not cause income inequality, and is not rejected for the crisis period. Based on these findings, we can conclude that both the Rajan and Acemoglu hypotheses are unconfirmed for Denmark.

Regarding Finland, Panel A in Fig. 4 posits that the null of inequality does not cause credit expansion, and is rejected for the 1959-1961, 1977-1980, and 2011-2013 sub-periods. Further, Panel C in Fig. 4 reveals that inequality positively impacts credit in these sub-periods, excluding the sub-period of 2011-2013. Additionally, Panel B in Fig. 4 indicates that credit only causes income inequality for the 1989-1994 sub-period, and Panel D reveals that credit expansion in this period increases income inequality. When these findings are evaluated by considering the 1931 and 1991 banking crises in Finland, the absence of both unidirectional causality from inequality to credit and a causal feedback relationship in the crisis period lead to the rejection of both 


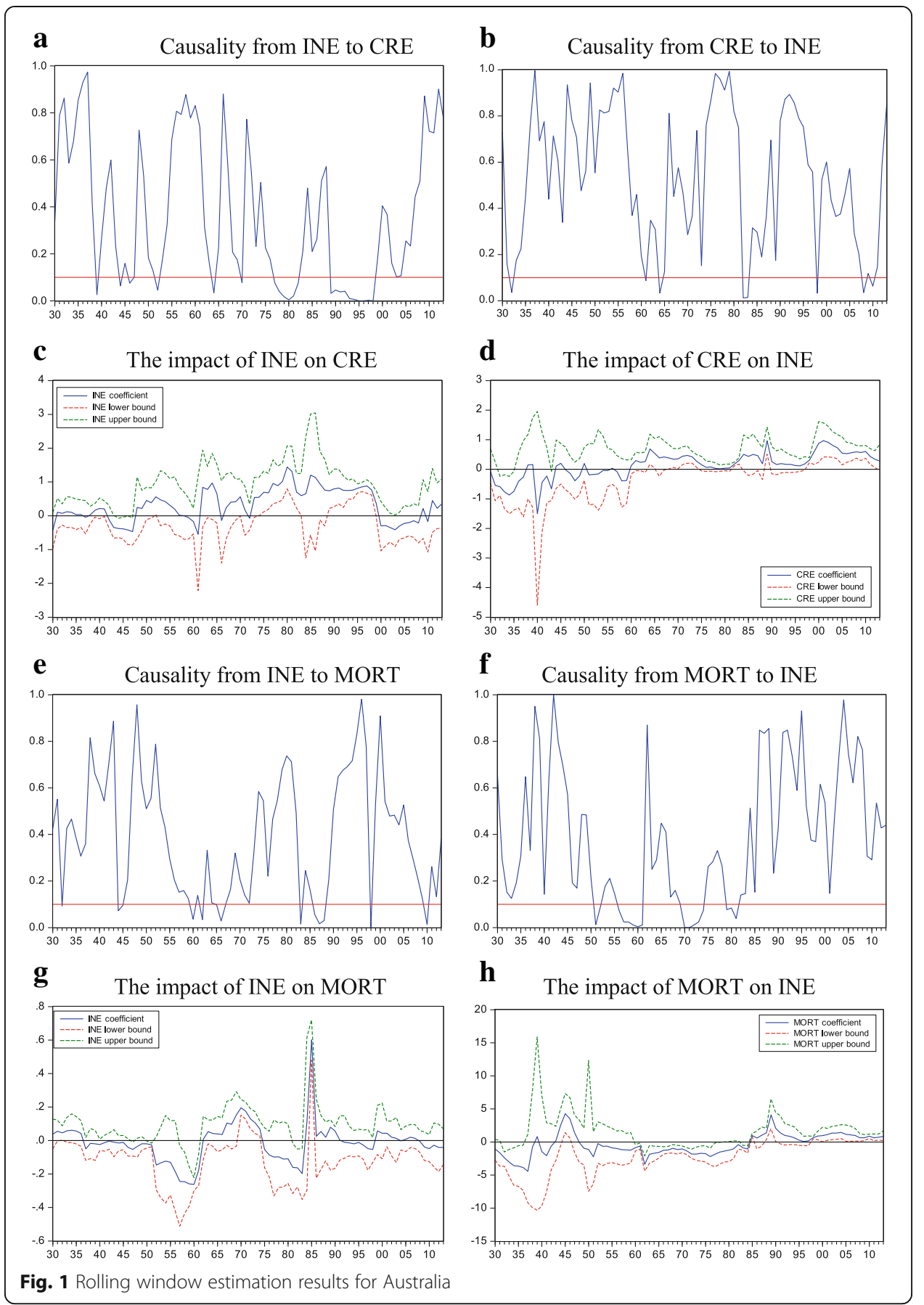

hypotheses. The existence of causality from credit to inequality and credit's positive effect on inequality in the crisis period may occur due to financial crises' increasing of inequality.

When the results are evaluated for France, Panel A in Fig. 5 indicates that income inequality caused credit expansions in the 1935-1938, 1958-1962, and 1998-2002 sub-periods. According to Schularick and Taylor (2012), France's banking crises emerged in 1930 and 2008; therefore, no causality exists between inequality and credit in these crisis periods. Additionally, Panel C in Fig. 5 reveals that inequality's impact on 


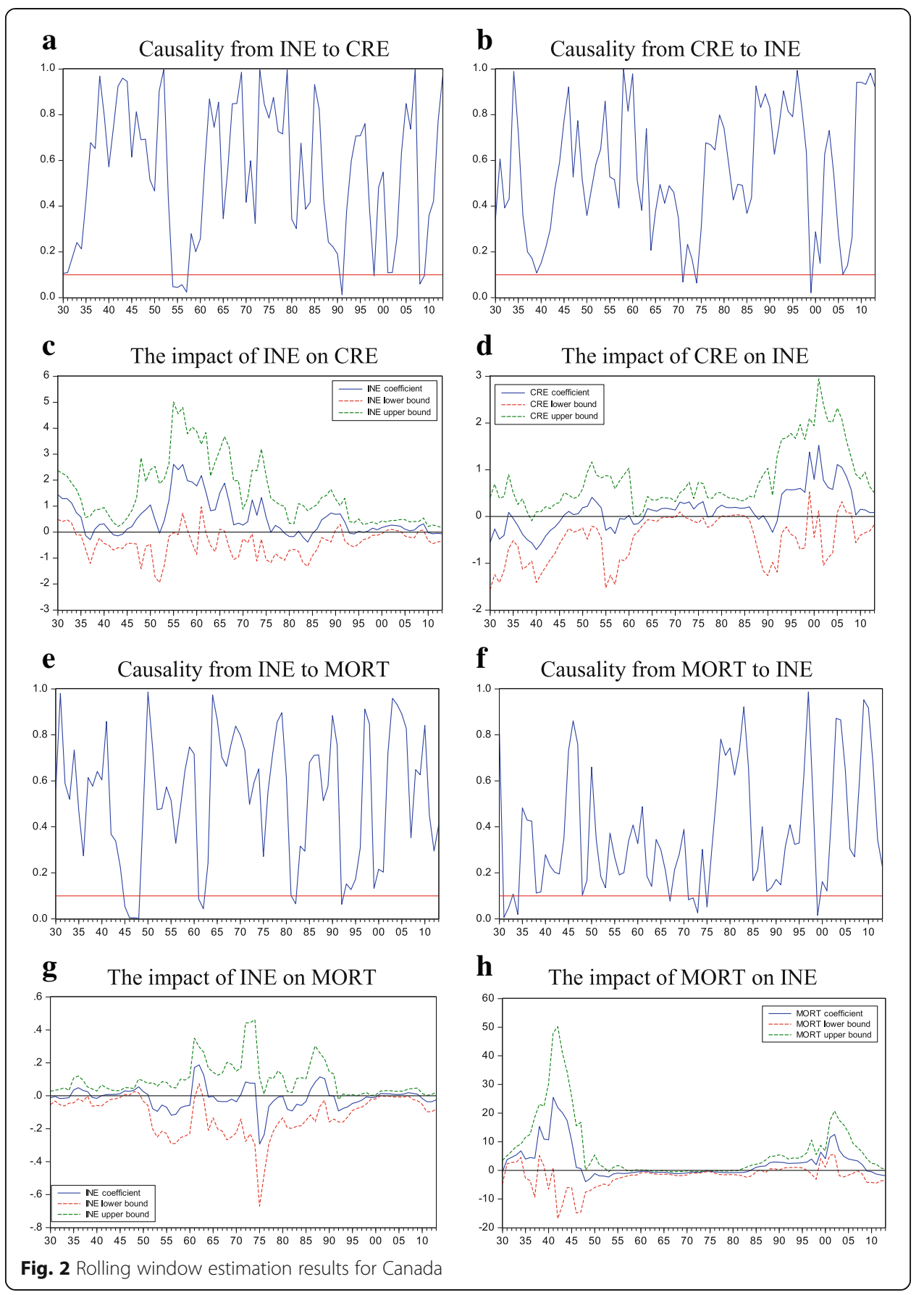

credit expansion was negative in the 1935-1938 and 1958-1962 sub-periods. Panel D in Fig. 5 also indicates that credit's impact on inequality is negative in crisis periods, thus rejecting the Acemoglu hypothesis.

In the case of the United Kingdom, as plotted in Panel A in Fig. 6, the null hypothesis-that income inequality does not Granger-cause credit booms-is rejected for the 1990-1996 and 2004-2008 sub-periods. Panel C in Fig. 6 also indicates that the coefficient of inequality has a positive effect on credit for these periods. Further, Panel B in Fig. 6 indicates that credit booms caused income inequality in the 1960-1967 and 

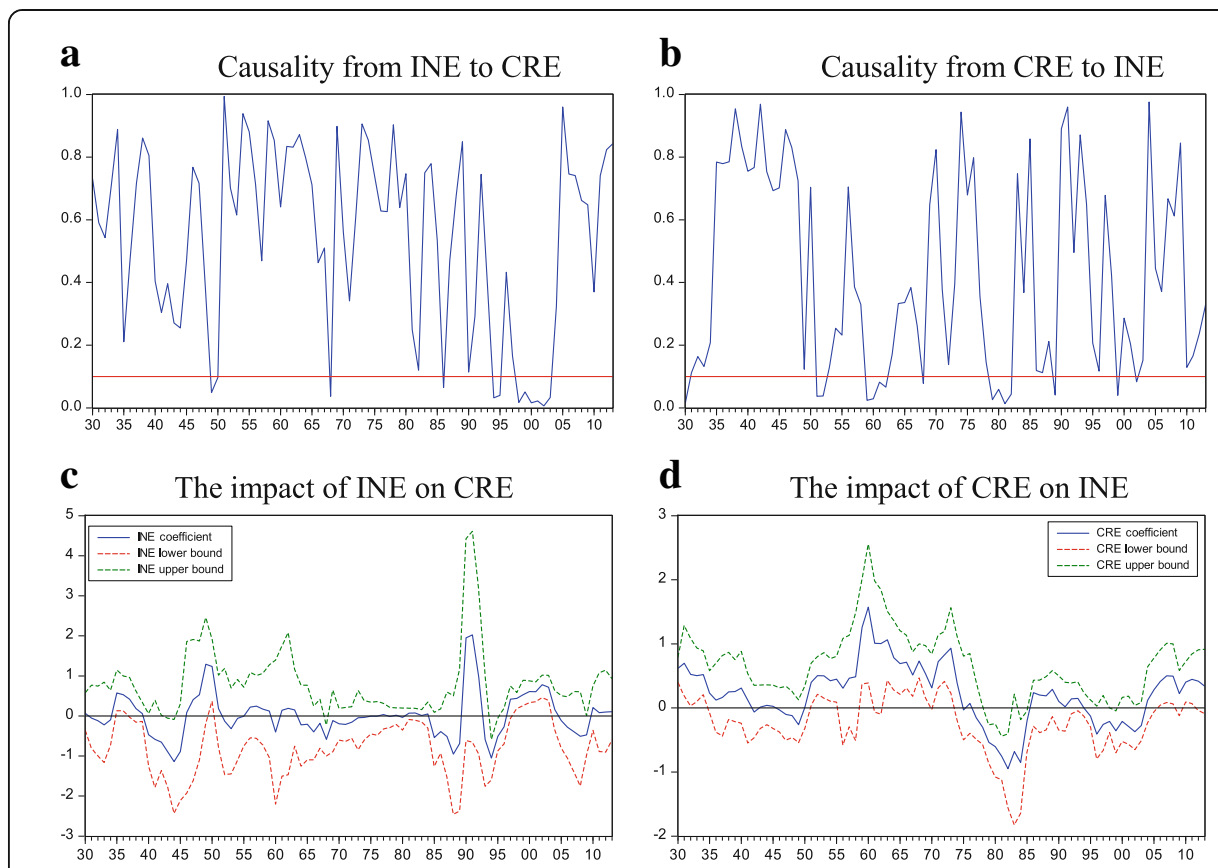

d The impact of CRE on INE
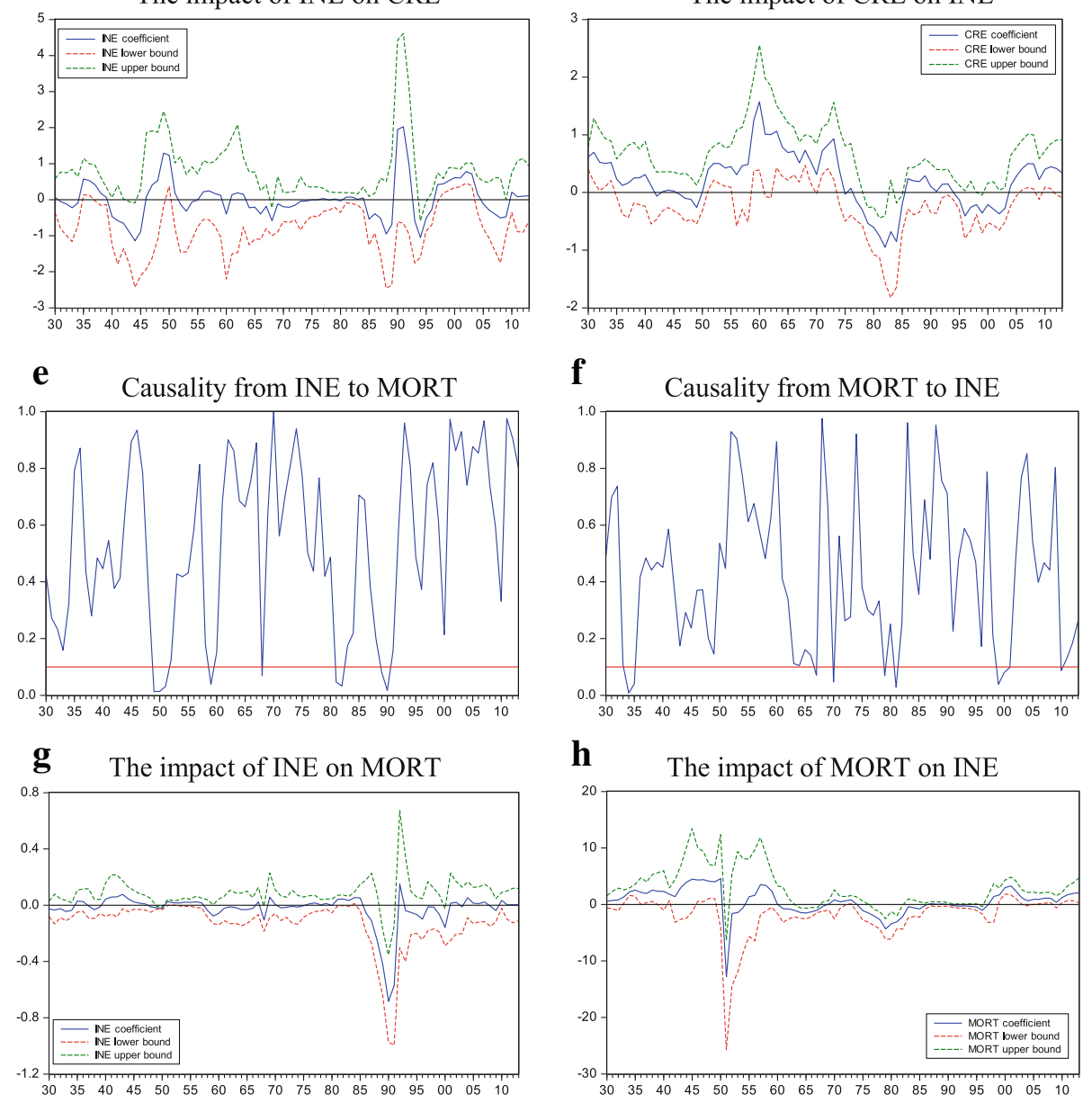

Fig. 3 Rolling window estimation results for Denmark

1991-1994 sub-periods. However, this study's results differ from the Acemoglu hypothesis in that credit's impact on inequality is negative for these sub-periods, as illustrated by Panel D in Fig. 6. If these findings are interpreted to consider the 1974, 1991, and 2007 banking crises in the United Kingdom, this seems to confirm the Rajan hypothesis in the United Kingdom for the 1991 and 2007 crises, but not for the 1974 crisis.

Regarding Japan, as can be observed from Panel A in Fig. 7, income inequality caused a credit boom in the 1902-1904, 1945-1956, 1982-1990, and 2004-2006 sub-periods. However, Schularick and Taylor's (2012) crisis database indicates that Japan's banking crises occurred in 1907, 1920, 1927, and 1997. Additionally, Panel C in Fig. 7 reveals that 


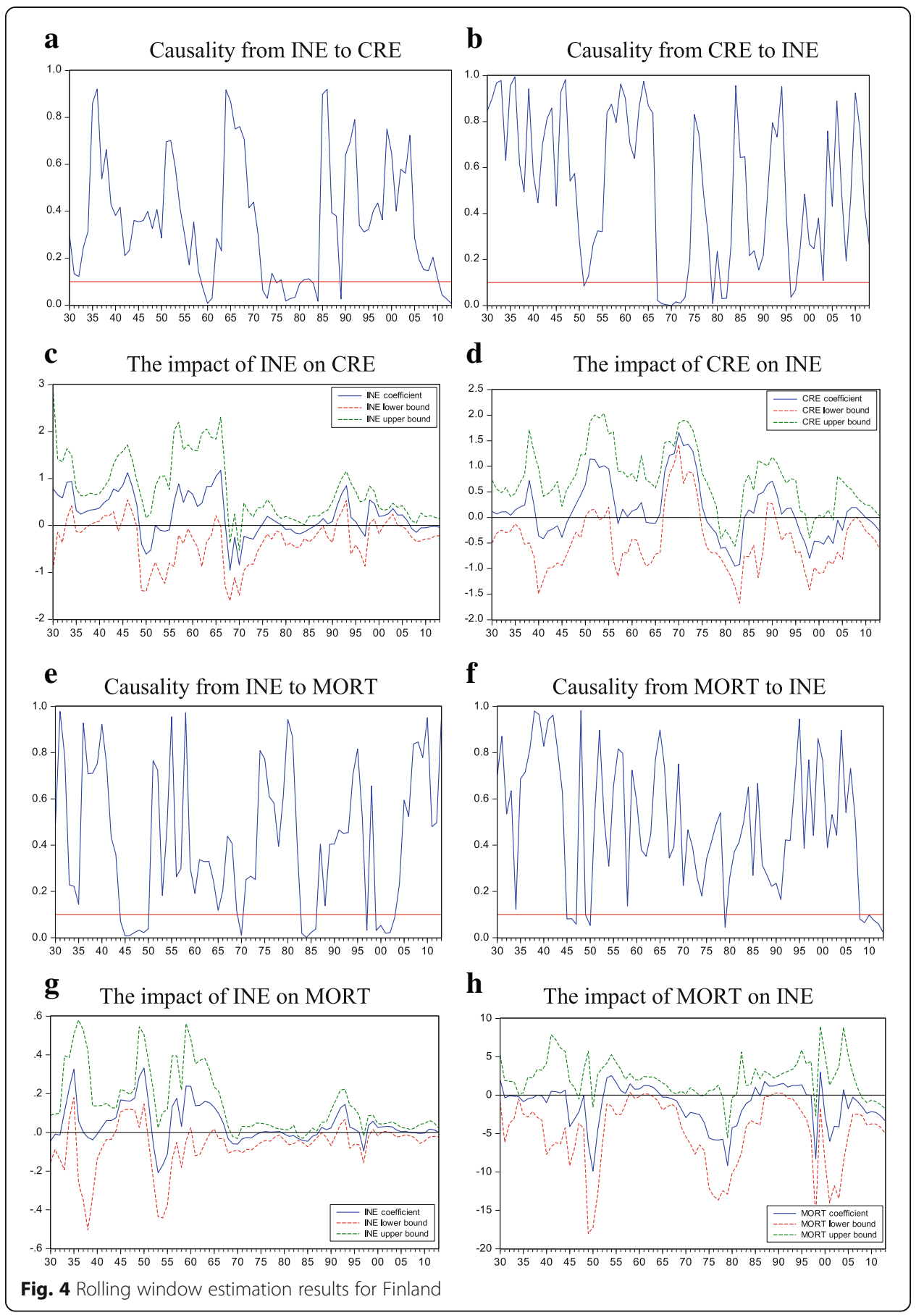

the causality from credit expansion to income inequality is also unconfirmed in these crisis periods. Therefore, neither the Rajan nor the Acemoglu hypotheses are valid for Japan.

In Norway, Panel A in Fig. 8 illustrates that the null hypothesis-that no causality exists from income inequality to credit boom-is not rejected for almost all periods. Similarly, as can be observed from Panel C in Fig. 8, causality from credit expansion to income inequality is found only for the 2002-2004 sub-period. However, Norway's systemic banking crisis occurred in 1988, and therefore, it can be concluded that this crisis cannot be associated with income inequality. 


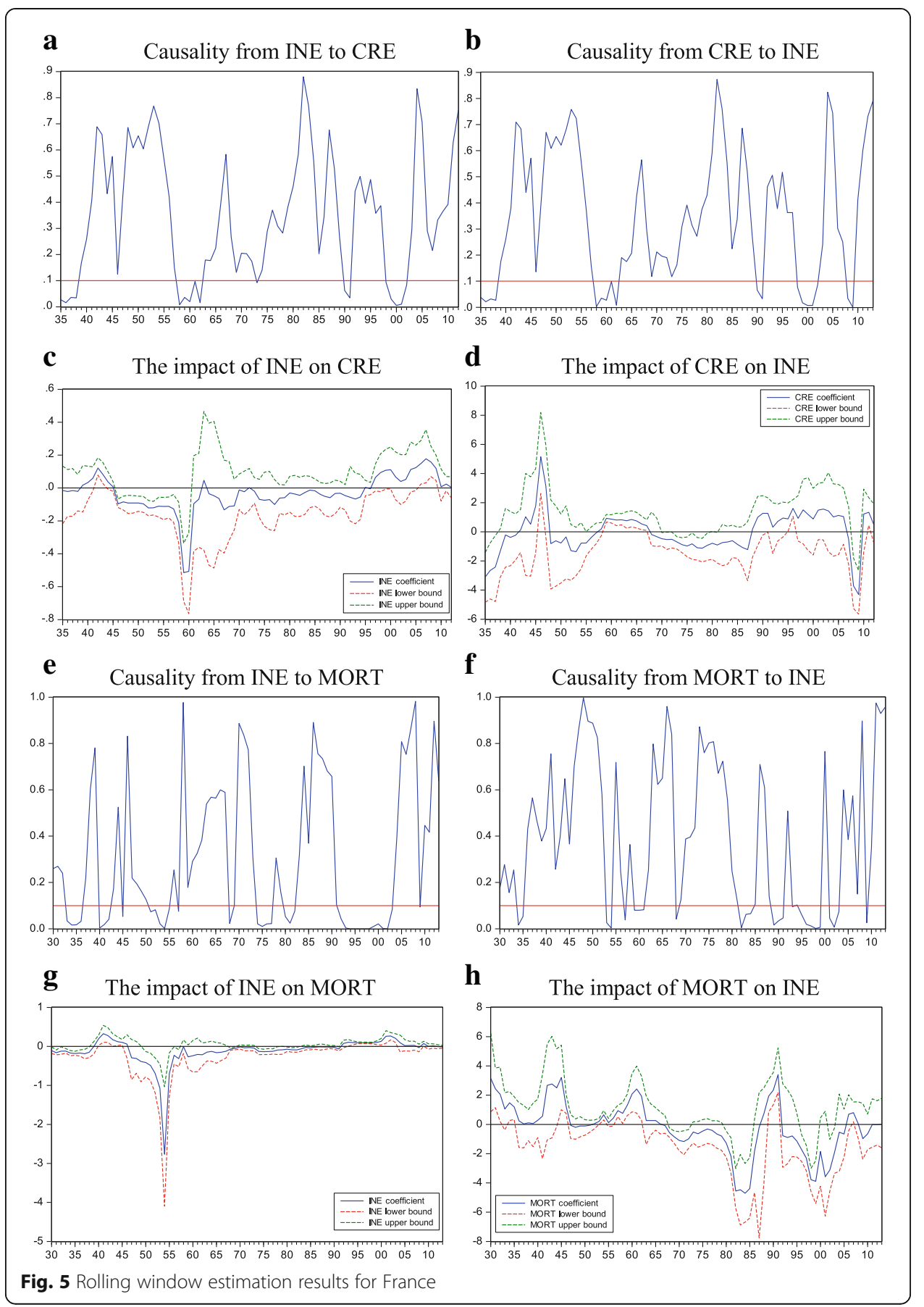

In the case of Sweden, we also examine the possible role of income inequality in financial crises using a rolling-window estimation, the results of which are plotted in Fig. 9. Panel A in this figure demonstrates that income inequality caused credit expansion in the 1974-1977, 1984-1988, and 1995-1998 sub-periods. Additionally, as indicated by Panel C in Fig. 9, the null-that credit expansion does not cause income inequality-is rejected only for the 2010-2012 sub-period. However, Sweden's banking crises emerged in 1991 and 2008. Based on the evidence that no causal relationship exists between inequality and credit in such periods, the Rajan hypothesis is rejected for Sweden. 

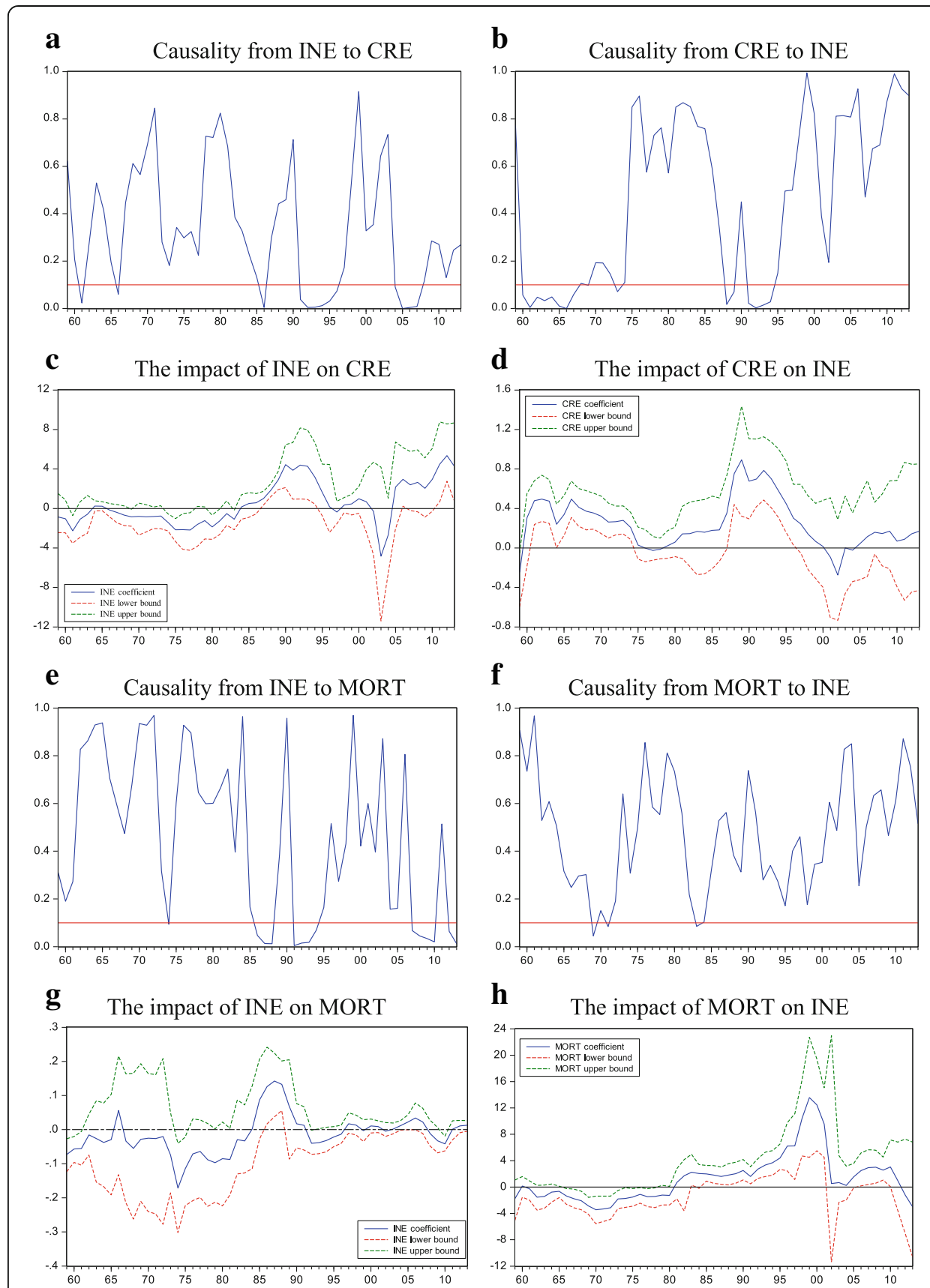

Fig. 6 Rolling window estimation results for the UK

Finally, Fig. 10 displays the rolling-window estimation results for the United States. Panel A in Fig. 10 illustrates that income inequality caused credit booms in the 1929-1942, 1997-2002, and 2005-2009 sub-periods. Further, as can be observed from Panel C in Fig. 10, the impact of income inequality on the credit boom is positive in these sub-periods. If the validity of the feedback relationship between inequality and crisis is searched in Panel B in Fig. 10, it seems that credit booms caused inequality in the 1923-1941 and 1983-1986 sub-periods. However, Panel D in Fig. 10 notes that the credit expansion's impact on income inequality is negative in the 1929-1954 sub-period. As the United States experienced banking crises in 1929, 1984, and 2007, we can 

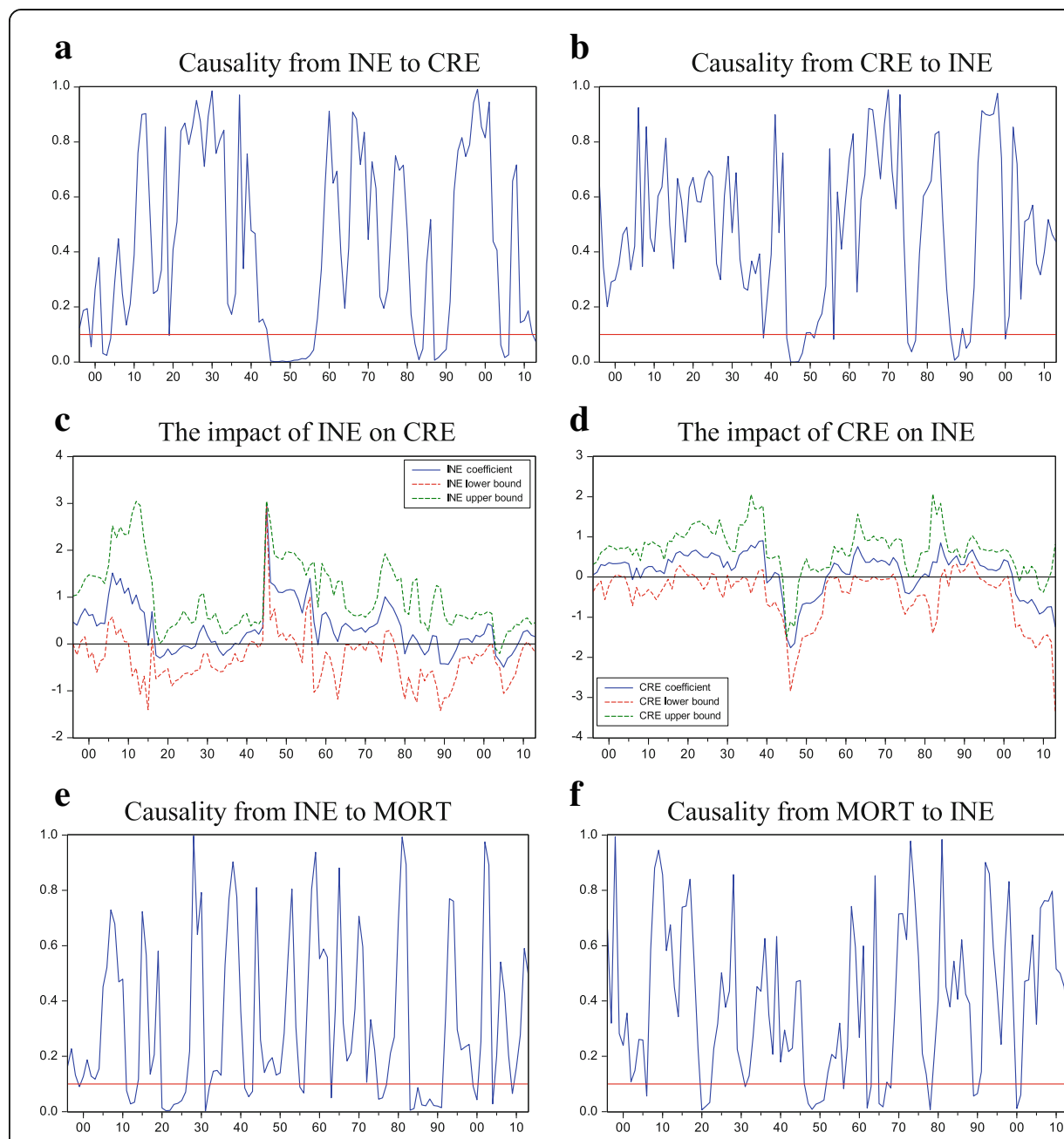

$\mathbf{f}$
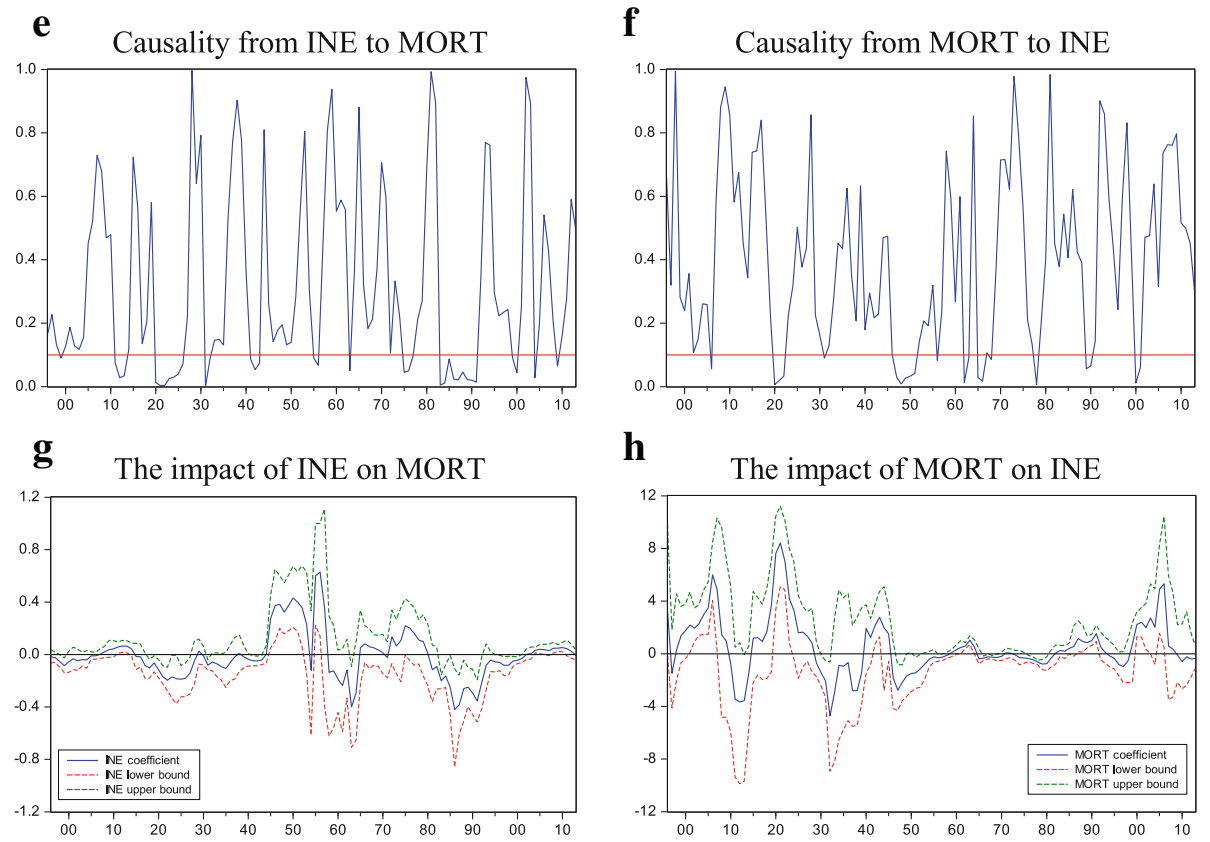

h

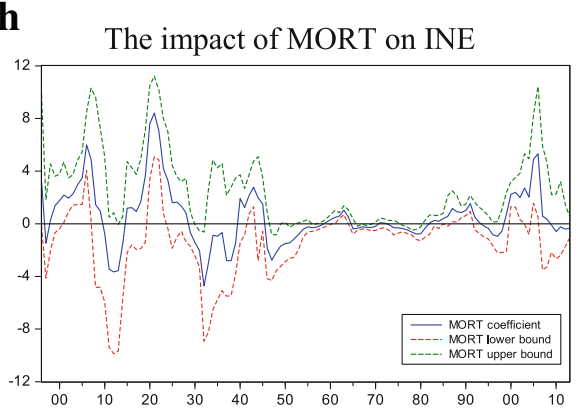

Fig. 7 Rolling window estimation results for Japan

conclude from our findings that the Rajan hypothesis is valid for the United States' 1929 and 2007 crises, although the hypothesis is not confirmed for the 1984 crisis.

To check robustness, we examine the relationship between income inequality and mortgage loans by employing a bootstrap rolling-window procedure. Panels E, F, G, and $\mathrm{H}$ in Figs. 1, 2, 3, 4, 5, 6, 7, 8, 9 and 10 plot the rolling-window estimation results for the inequality-mortgage loan nexus. Panels $\mathrm{E}$ and $\mathrm{F}$ in each figure illustrate the bootstrap $p$-values of the rolling test statistics, which test whether the null hypothesis of income inequality does not Granger-cause mortgage loans, and vice versa. Panels G 

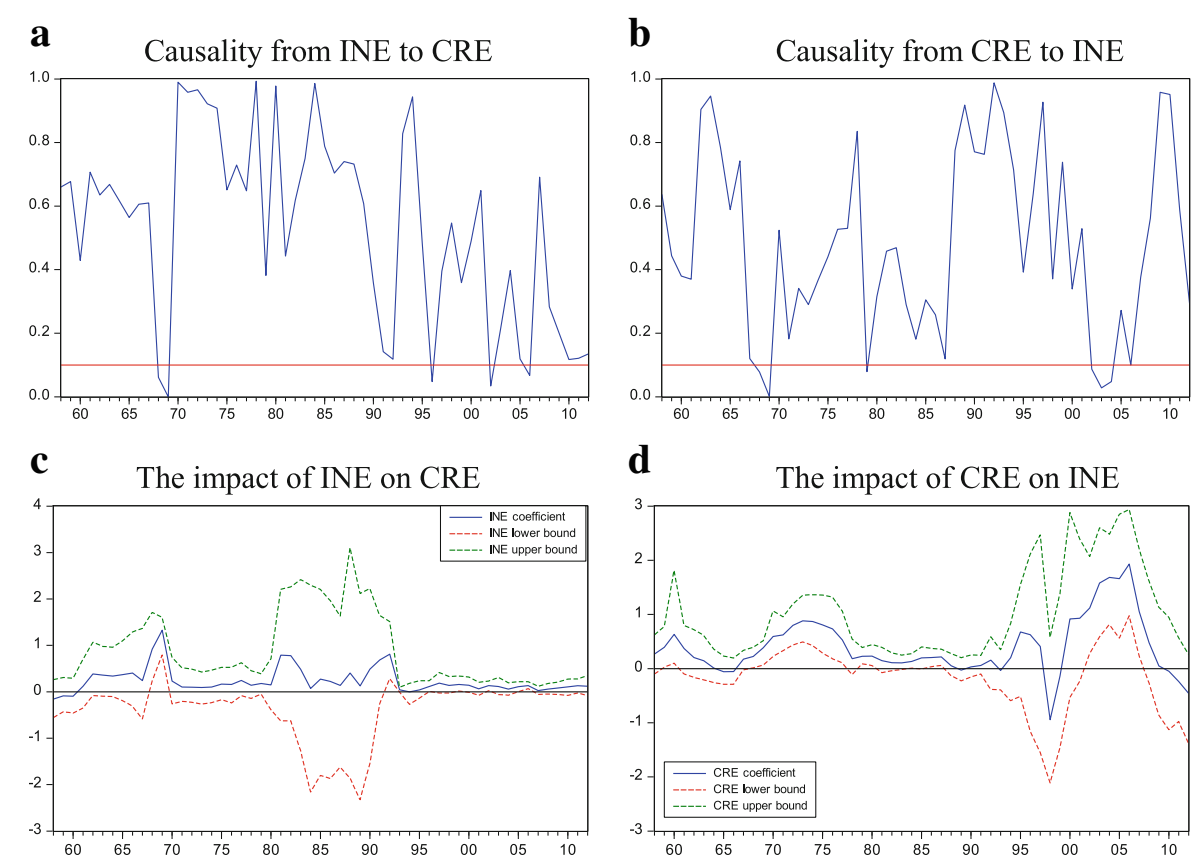

d
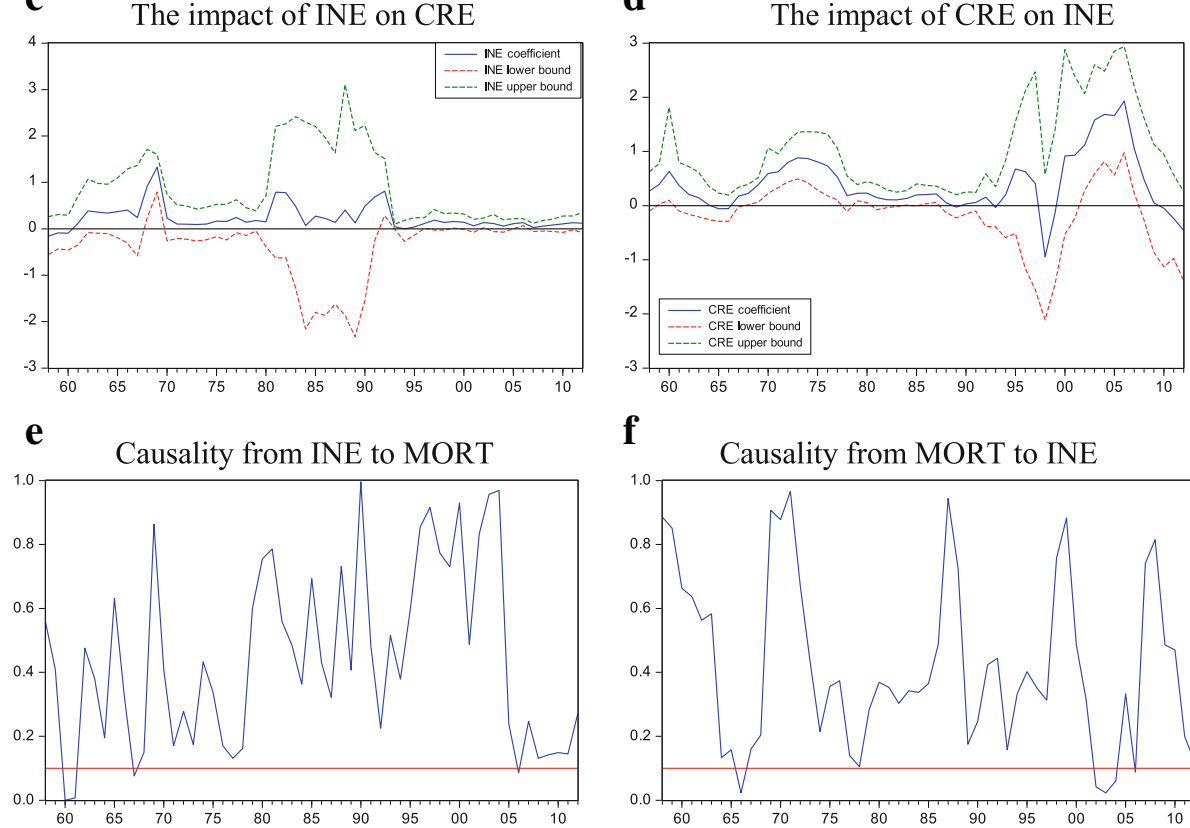

f

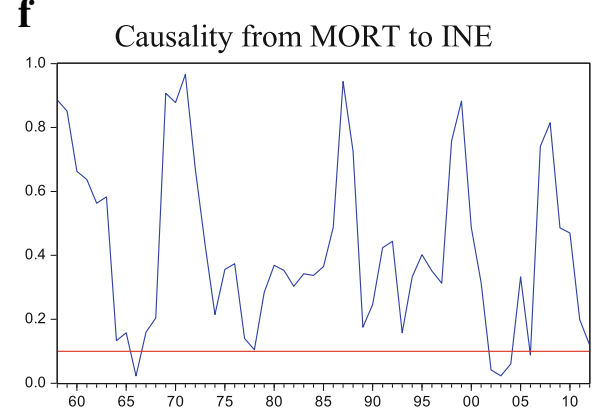

g The impact of INE on MORT

h

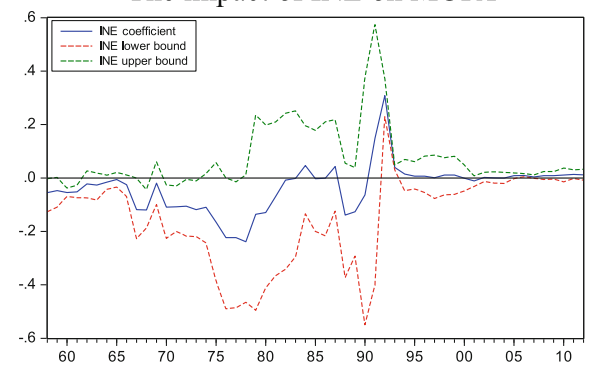

The impact of MORT on INE

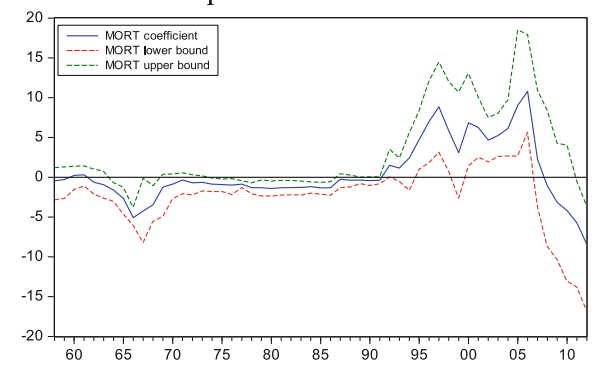

Fig. 8 Rolling window estimation results for Norway

and $\mathrm{H}$ in each figure display the bootstrap estimates of sum of the rolling coefficients, measuring income inequality's effect on credit expansion, and vice versa. These results, particularly those in Panels E and G in Fig. 1, indicate that income inequality caused mortgage loans for the 1986-1989 sub-period, which covers Australia's 1989 crisis.

Additionally, consistent with previous findings, Panel E in Fig. 6 reveals that the causality from inequality to mortgage loans is confirmed for the 1991 and 2007 crises in the United Kingdom, and with increasing income inequality positively impacting mortgage 


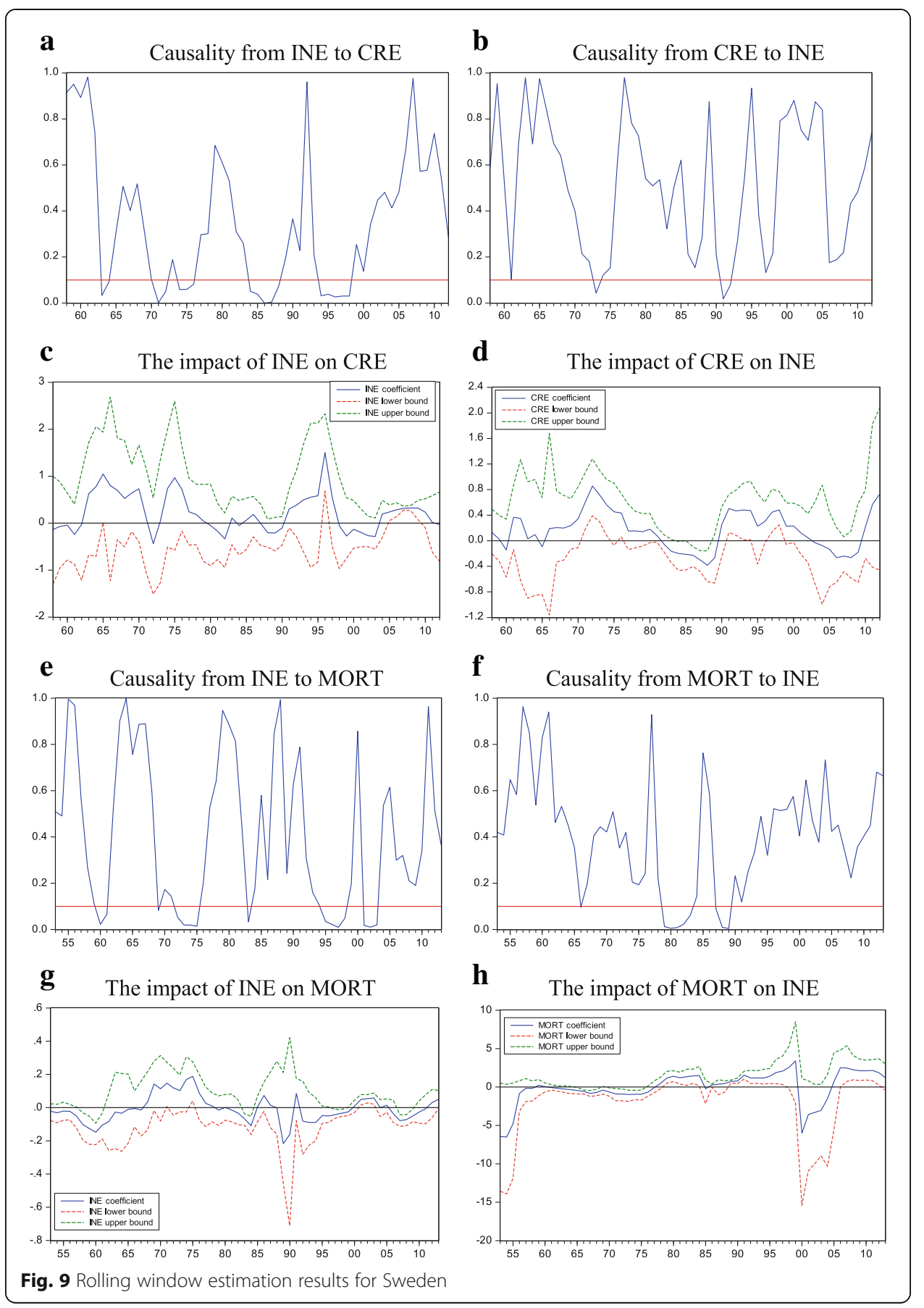

loans in these periods. However, no causal relationship exists between inequality and mortgage loans for the United Kingdom's 1974 crisis. Moreover, the finding that inequality caused a credit expansion in the United States' 1929 and 2007 crises is also validated by using mortgage loans as an indicator of financial crises. According to Panel E in Fig. 10, a causality from inequality to mortgage loans seems to exist for the 1923-1932 and 2007-2009 sub-periods, but no causal linkage exists between the variables for the United States' 1984 crisis. 

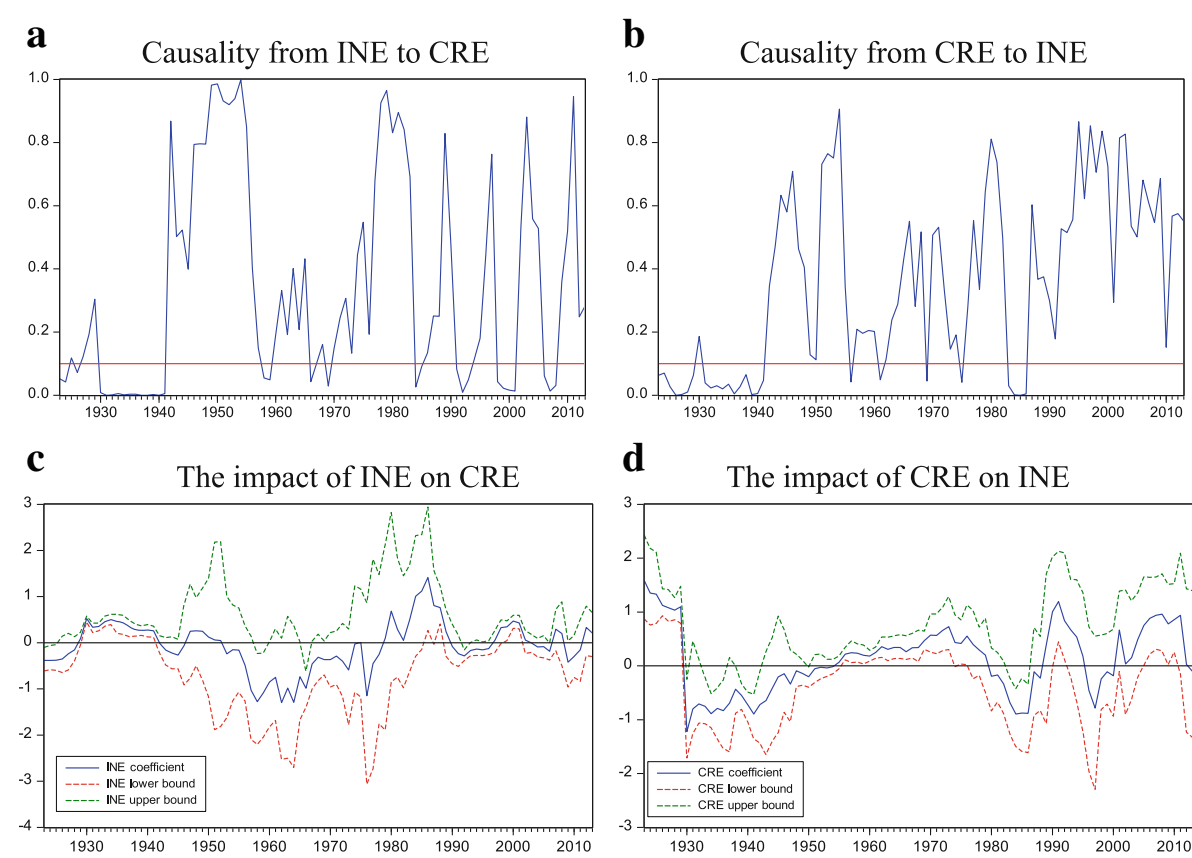

d The impact of CRE on INE
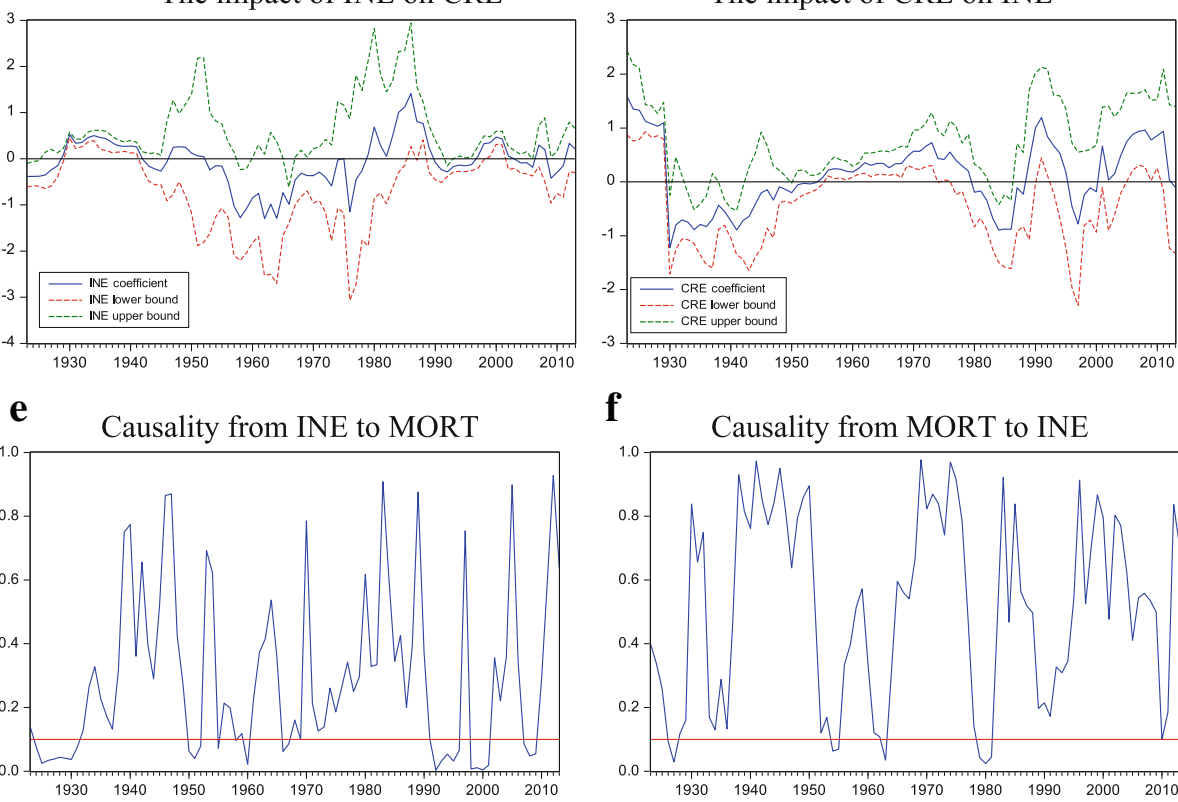

f
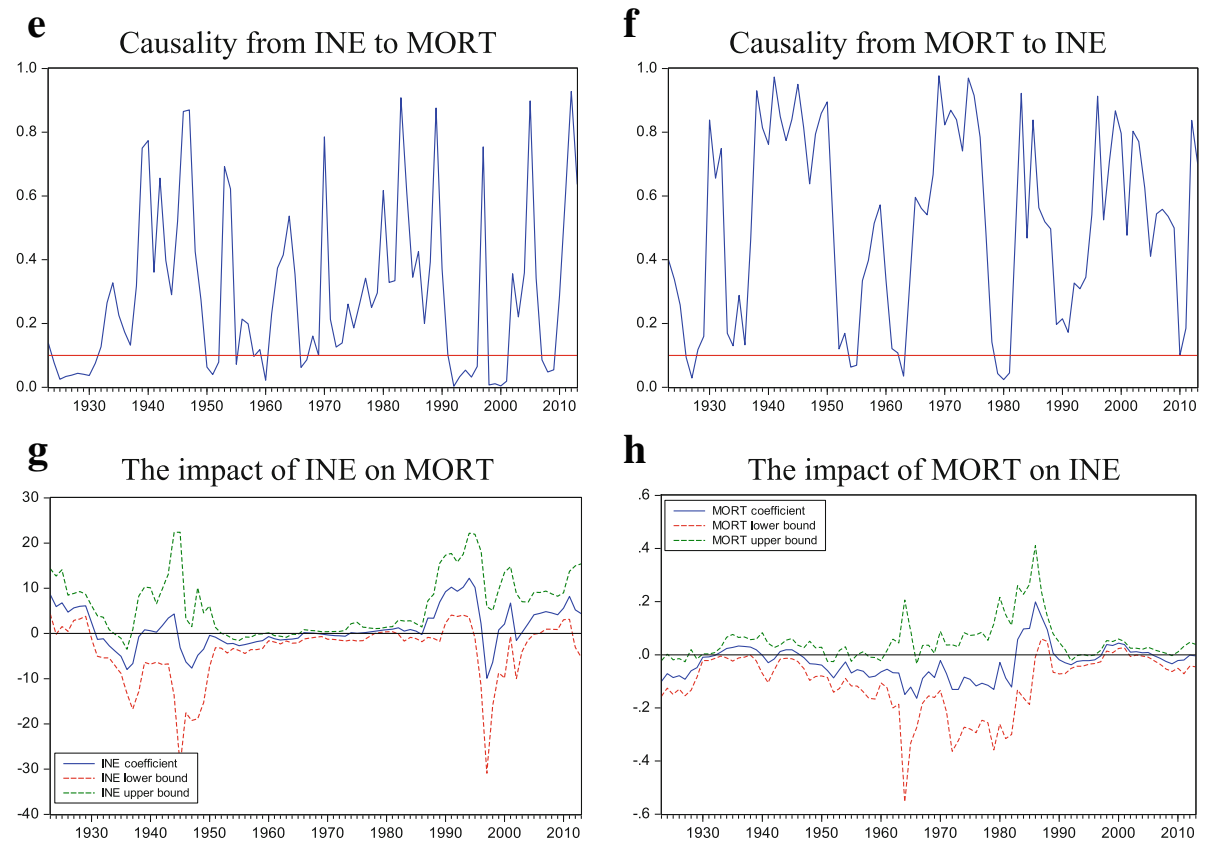

h

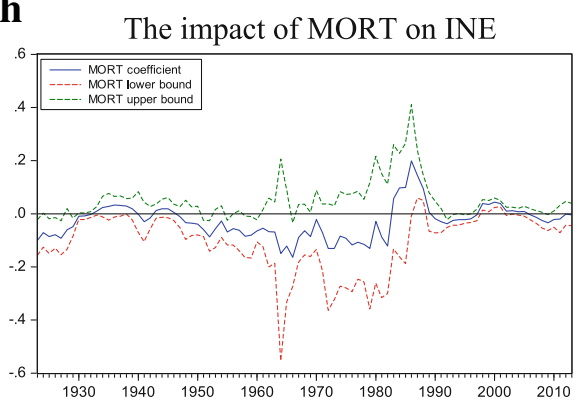

Fig. 10 Rolling window estimation results for the US

The Rajan hypothesis argues that increasing income inequality and financial deregulation policies to facilitate low-income households' credit access plays a key role in financial crises. Overall, our findings confirm this for the 1989 crisis in Australia, the 1991 and 2007 crises in the United Kingdom, and the 1929 and 2007 crises in the United States. Regarding Australia, it was observed that the income inequality-or the share of the highest income with a $1 \%$ share in total income-was $4.4 \%$ in 1981. After this year, the share of $1 \%$ of income (income inequality) continuously increased to 6.94\% until 1989, when Australia's 
financial crisis occurred. An examination of the Australian economic policies in the previously mentioned period revealed that a financial deregulation policy was introduced in Australia in 1983. As a result, housing prices increased by 17\% in real terms until 1990, while the share of corporate debt in the national income increased to 60\% (Gizycki and Lowe 2000). Therefore, Rajan's claims of increasing inequality as well as a subsequent financial deregulation policy are consistent with our findings.

Regarding the United Kingdom, income inequality was $11.47 \%$ in 1950, then continuously decreased to $6.54 \%$ until 1974 , when the first crisis occurred. It was then observed that this increased to $10.32 \%$ until the second crisis in 1991. This percentage then increased to $15.44 \%$ in 2007 . The fact that inequality significantly increased before the crises in 1991 and 2007 is consistent with our findings for the United Kingdom. Income inequality in the United States, particularly before the 1929 and 2007 crisis periods, indicates that inequality increased from $14.46 \%$ in 1920 to $19.6 \%$ in 1928. Similarly, observing the dimensions of income inequality before the 2007 crisis reveals an inequality of $7.8 \%$ in 1970, which increased to $18.33 \%$ in 2007. In short, the inequality in 2007 approached levels observed prior to the Great Depression in the United States. Additionally, the fact that financial deregulation policies were implemented before both crises explains our findings' consistency.

These findings confirm the primary argument that income inequality played a key role in financial crises in Anglo-Saxon countries (Australia, the United Kingdom, and the United States), and this may have originated from the Anglo-Saxon welfare state model, which involves minimum regulatory policies and low-level social transfers. Alternatively, the Rajan hypothesis is unconfirmed for countries that follow Scandinavian or continental European welfare state models.

\section{Conclusions and policy implications}

This study aimed to examine the possible role of income inequality in financial crises by using historical data from 10 developed countries. For this purpose, the relationship between the Gini coefficient and credit expansion is investigated using the full-sample bootstrap Granger causality and bootstrap rolling-window estimation procedures.

The full-sample bootstrap Granger causality test results indicate that a unidirectional causality exists from income inequality to credit expansion for Australia, Canada, Sweden, and the United States. This finding suggests the Rajan hypothesis' validity in these countries. Moreover, a bidirectional causality exists in Japan between income inequality and credit expansion as argued by the Acemoglu hypothesis, although this finding reveals that no causal connection exists between inequality and credit expansion in Finland, France, and Norway. After this procedure, we employed parameter stability tests to determine the reliability of the full sample's findings, the results of which reject parameter stability for all countries. Therefore, we conclude that the previous studies based on parameter stability and the assumption of a stable relationship over the full sample may be unreliable. Consequently, we used a rolling-window estimation procedure to observe the causal linkages among the sub-samples.

The rolling-window estimation results imply that inequality had a positive, predictive role on credit booms in Australia's 1989 crisis, the 1991 and 2007 crises in the United Kingdom, and the 1929 and 2007 crises in the United States. Therefore, the Rajan hypothesis is confirmed for these crises. These findings are similar to those from Gu and Huang (2012) and Ahlquist and Ansell (2012) regarding the countries in which the hypothesis is valid. 
However, this study contrasts these works by revealing that the hypothesis is valid for certain financial crises, contrary to the claim that the Rajan hypothesis is valid for all financial crises experienced in the previously mentioned countries. On one hand, evaluating the countries where income inequality played an active role in their financial crises (Australia, the United Kingdom, and the United States) indicates that they have connected with the Anglo-Saxon welfare state model, which involves minimum income-redistribution and regulatory policies in the labor market. On the other hand, it can be argued that the countries where income inequality did not play a key role in financial crisis depend on the Scandinavian welfare state model (Denmark, Finland, Norway, and Sweden), which is based on the fair distribution of income and social inclusion principles, as well as the continental European welfare state model (France), in which ownership and individual enterprises exist based on strict governmental control.

Based on these findings, it is possible to argue that policy measures to deter the problems of increased income inequality and facilitate credit access among low-income segments by deregulating certain sectors will increase repayment risks and create pressure on the financial system. Therefore, this study's findings suggest that a progressive taxation policy or investments to accumulate human capital and increase the qualified labor force are more rational than temporary solutions, such as decreasing loan interest rates to facilitate access of low-income segments to financial instruments. The increase in human capital investments will also help lower the inequality of education in the society by raising the level of education of low-income people who are unable to increase their income level and help them to work with higher wages which reduce the income inequality in the society.

Finally, there are some limitations of this study. First, this study uses time series methods and the shock dependence between countries is ignored. Therefore, in the future studies, the role of the income inequality in the crisis of observed countries can be examined with the second-generation panel data methods which take into account the cross-sectional dependence among countries. Furthermore, this paper only considers the developed countries due to lack of data set. In future studies, the effects of income inequality especially for developing economies should be examined.

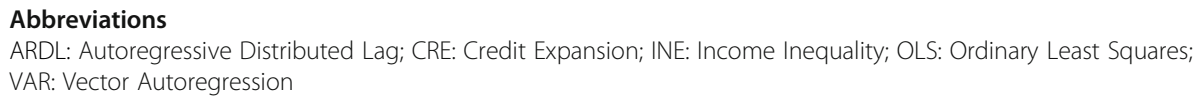




\section{Publisher's Note}

Springer Nature remains neutral with regard to jurisdictional claims in published maps and institutional affiliations.

\section{Received: 3 October 2018 Accepted: 15 April 2019}

Published online: 05 May 2019

\section{References}

Acemoglu D. (2011). Thoughts on inequality and the financial crisis, http://economics.mit.edu/files/6348

Ahlquist, JS, Ansell B (2012). Electoral institutions, credit, and political responses to economic polarization, unpublished Mimeo

Andrews DWK (1993) Tests for parameter instability and structural change with unknown change point. Econometrica 61: $821-856$

Andrews DWK, Ploberger W (1994) Optimal tests when a nuisance parameter is present only under the alternative. Econometrica 62:1383-1414

Balcilar M, Ozdemir ZA, Arslanturk Y (2010) Economic growth and energy consumption causal nexus viewed through a bootstrap rolling window. Energy Econ 32(6):1398-1410

Bernanke BS, Gertler M, Gilchrist S (1999) The financial accelerator in a quantitative business cycle framework. Handbook of Macroeconomics 1:1341-1393

Bordo MD, Meissner CM (2012) Does inequality lead to a financial crisis? J Int Money Financ 31(8):2147-2161

Borio C, Furfine C, Lowe P (2001) Procyclicality of Financial Systems and Financial Stability: Issues and Policy Options. BIS Paper no. 1, Bank for International Settlements, Basel

Carrion-i-Silvestre JL, Kim D, Perron P (2009) GLS-based unit root tests with multiple structural breaks under both the null and the alternative hypotheses. Economet Theor 25(6):1754-1792

Corsetti C, Pesenti P, Roubini N (1999) What caused the Asian currency and financial crisis? Jpn World Econ 11(3):305-373

Dell'Ariccia G, Marquez R (2006) Lending booms and lending standards. J Financ 51(5):2511-2546

Dosi G, Fagiolo G, Napoletano M, Roventini A (2013) Income distribution, credit and fiscal policies in an agent-based Keynesian model. J Econ Dyn Control 37(8):1598-1625

Efron B (1979) Bootstrap methods: another look at the jackknife. Ann Stat 7:1-26

Fasianos A, Raza H, Kinsella S (2017) Exploring the link between household debt and income inequality: an asymmetric approach. Applied Economics Letters 24(6): 404-409

Fisher I (1932) Booms and depressions. Adelphi, New York

Fisher I (1933) The debt-deflation theory of great depressions. Econometrica 1(4):337-357

Galbraith JK (2012) Inequality and instability: a study of the world economy just before the great crisis. Oxford University Press, Oxford

Gizycki M, Lowe P (2000) The Australian financial system in the 1990s. In: Australian Economy in the 1990s. Proceedings of a conference, Reserve Bank of Australia, Sydney, pp 180-215

Gu X, Huang B (2012) An empirical examination of the inequality, leverage and crisis nexus, (Mimeo)

Hacker RS, Hatemi-J A (2006) Tests for causality between integrated variables using asymptotic and bootstrap distributions: theory and application. Appl Econ 38(13):1489-1500

Kashif M, Iftikhar SF, Iftikhar K (2016) Loan growth and bank solvency: evidence from the Pakistani banking sector. Financ Innov 2(1):22

Kindleberger CP (1978) Manias, panics, and crashes: a history of financial crisis. Basic Books, New York

Kirschenmann K, Malinen T, Nyberg H (2016) The risk of financial crises: is there a role for income inequality? J Int Money Financ 68:161-180

Krueger A (2012) The Rise and Consequences of Inequality in the United States, presentation at the Center for American Progress, Washington 12 January 2012, http://www.whitehouse.gov/sites/default/files/krueger_cap_ speech_final_remarks.pdf

Kumhof M, Rancière R, Winant P (2015) Inequality, leverage, and crises. Am Econ Rev 105(3):1217-1245

Lorenzoni G (2005) 'Inefficient credit booms', Department of Economics (online), Massachusetts institute of technology

Mahmoud S, Niguez TM (2015) Does income inequality have a role in financial crises?

Malinen T (2013) Is there a relationship between income inequality and credit cycles? In: Society for the study of economic inequality working paper series, pp 2013-2292

Milanovic B (2009) Two views on the cause of the global crisis_-part I. Yale Global Online http://yaleglobal.yale.edu/content/ two-views-global-crisis

Minsky HP (1975) John Maynard Keynes. McGraw-Hill Professional, New York

Minsky HP (1982) Can 'It' Happen Again? Essays on Instability and Finance. M. E. Sharpe, Armonk

Minsky HP (1986) Stabilizing an unstable economy. McGraw-Hill Professional, New York

Palley T (2012) From financial crisis to stagnation: the destruction of shared prosperity and the role of economics. Cambridge University Press, Cambridge

Perugini C, Hölscher J, Collie S (2015) Inequality, credit and financial crises. Cambridge Journal of Economics 40(1): 227-257

Phillips PCB, Hansen BE (1990) Statistical inference in instrumental variables regression with I (1) processes. Rev Econ Stud 57:99-125

Rajan R (1994) Why bank credit policies fluctuate: a theory and some evidence. Q J Econ 109:399-441

Rajan RG (2010) Fault Lines. Princeton University Press, Princeton

Reich R (2010) Aftershock: the next economy and America's future. Knopf, New York

Roubini N (2011). The Instability of Inequality, https://www.project-syndicate.org/commentary/the-instabilityofinequality?barrier=accesspaylog

Russo A, Riccetti L, Gallegati M (2016) Increasing inequality, consumer credit and financial fragility in an agent based macroeconomic model. J Evol Econ 26(1):25-47 
Schularick M, Taylor AM (2012) Credit booms gone bust: monetary policy, leverage cycles, and financial crises, 1870-2008. Am Econ Rev 102(2):1029-1061

Stiglitz JE (2012) The Price of inequality: how Today's divided society endangers our future. W. W. Norton, Princeton

Toda HY, Yamamoto T (1995) Statistical inference in vector autoregressions with possibly integrated processes. J Econ 66(1):225-250

Van Treeck T (2014) Did inequality cause the US financial crisis. J Econ Surv 28(3):421-448

Yamarik S, El-Shagi M, Yamashiro G (2016) Does inequality lead to credit growth? Testing the Rajan hypothesis using statelevel data. Econ Lett 148:63-67

Submit your manuscript to a SpringerOpen ${ }^{0}$ journal and benefit from:

- Convenient online submission

- Rigorous peer review

Open access: articles freely available online

- High visibility within the field

- Retaining the copyright to your article

Submit your next manuscript at $\boldsymbol{\nabla}$ springeropen.com 